\title{
Tulane
}

\author{
Tulane Economics Working Paper Series
}

\section{Using Dynamic Panel Methods to Estimate Shadow Economies Around the World, 1984-2006}

\author{
James Alm \\ Department of Economics \\ Tulane University \\ New Orleans, LA \\ jalm@tulane.edu
}

\author{
Abel Embaye \\ Department of Economics \\ University of Arkansas \\ Fayetteville, AR \\ aembaye@walton.uark.edu
}

Working Paper 1303

February 2013

\begin{abstract}
The paper estimates the size of shadow economy for 111 countries for the years 1984 to 2006 based on the currency demand approach. An important innovation is our use of dynamic panel data methods, which allows us to make several important contributions. First, we estimate the shadow economy for a range of heterogeneous countries that previously could not be included in the same regression. Second, we include variables that measure institutional quality in countries, including a variable that measures enforcement efforts. Third, we account for the persistence of currency demand as it evolves over time. Our results indicate a substantial shadow economy across countries, ranging from 10 to 86 percent of GDP, with some tendency to grow over time. We also find that the shadow economy varies significantly by country income group. The mean shadow economy is 17 percent of GDP for OECD countries, 24 percent for non-OECD high income countries, 33 percent for upper middle income countries, 37 percent for lower middle income countries, and 38 percent for low income countries.
\end{abstract}

Keywords: tax evasion, shadow economy, currency demand method, panel data JEL: H21, H26, C33, E41, O17 


\title{
Using Dynamic Panel Methods to Estimate Shadow Economies AROUND THE W ORLD, 1984-2006
}

\author{
James Alm and Abel Embaye*
}

\begin{abstract}
* Tulane University and University of Arkansas. Please address all correspondence to Abel Embaye, Department of Economics, University of Arkansas, Business Building 402, Fayetteville, AR 72701, USA (phone +1 479575 4361; email aembaye@,walton.uark.edu).
\end{abstract}

\begin{abstract}
The paper estimates the size of shadow economy for 111 countries for the years 1984 to 2006 based on the currency demand approach. An important innovation is our use of dynamic panel data methods, which allows us to make several important contributions. First, we estimate the shadow economy for a range of heterogeneous countries that previously could not be included in the same regression. Second, we include variables that measure institutional quality in countries, including a variable that measures enforcement efforts. Third, we account for the persistence of currency demand as it evolves over time. Our results indicate a substantial shadow economy across countries, ranging from 10 to 86 percent of GDP, with some tendency to grow over time. We also find that the shadow economy varies significantly by country income group. The mean shadow economy is 17 percent of GDP for OECD countries, 24 percent for non-OECD high income countries, 33 percent for upper middle income countries, 37 percent for lower middle income countries, and 38 percent for low income countries.
\end{abstract}

Keywords: tax evasion, shadow economy, currency demand method, panel data

JEL classification: H21, H26, C33, E41, O17 


\section{Introduction}

The presence of untaxed activities - known as the "shadow economy", the "black economy", the underground economy", among other terms - is a common occurrence in all countries around the world. Its presence distorts resource allocation, changes the distribution of income in unpredictable ways, and reduces tax collections. In response, governments take many steps to reduce its size. However, these efforts require knowledge of its size, and such estimates are quite difficult to generate. Many methods have been developed to estimate the size of the shadow economy; see especially Schneider and Enste (2000) and Schneider (2005) for comprehensive disccussions of these methods and their resulting estimates. In this paper we build on this previous research. We apply dynamic panel estimation methods to the currency demand method, in order to estimate the size of the shadow economy for 111 countries for the years 1984 to 2006 .

The shadow economy is in fact somewhat difficult to define. Schneider (2005) defines the shadow economy as including all market-based legal production of goods and services that are deliberately concealed from public authorities to avoid payment of income, value added or other taxes, to avoid payment of social security contributions, to avoid certain legal labor market standards (e.g., minimum wages, safety standards), or to avoid certain administrative procedures (e.g., completing statistical questionnaires). A somewhat broader definition of the shadow economy includes all economic activities that contribute to the officially calculated gross national (or domestic) product but that are not included in these accounts (Alm, MartinezVazquez, and Schneider, 2004); relatedly, the shadow economy could be defined as all marketbased but unreported income from the production of legal goods and services, either from monetary or barter transactions, that would normally be taxable if they were reported to the tax 
authorities. Other definitions are of course possible. In this paper, our definition of the shadow economy follows Smith (1984), and is also similar to the definition used by Feige (1989), Fleming, Roman, and Farrel (2000), and Dell'Anno and Schneider (2003): the shadow economy includes all market-based goods and services (legal or illegal) that escape inclusion in official accounts.

As discussed in more detail later, estimating the size of the shadow economy using the currency demand approach has attracted much attention over the years (Tanzi, 1980, 1983; Matthews, 1982; Klovland, 1984; Bajada, 1999; Giles, 1999; Schneider, 2002; Giles and Tedds, 2002). However, almost all of existing studies have been done for developed countries. ${ }^{1}$ The shadow economies in developing countries are almost certainly higher, perhaps due to the inefficiencies of their tax administrations and to the larger sizes of their informal sectors. Obtaining estimates of the shadow economy in such countries is especially important but also especially difficult, due largely to inadequate data. However, data constraints are now somewhat easing, and it seems an opportune time to apply the currency demand approach to new data and to use new econometric techniques, in order to estimate the size of the shadow economy in developed and, especially, in developing countries.

In this paper, we estimate the size of the shadow economy for a panel of OECD and nonOECD countries. We make several specific and important innovations to this literature, all of which relate to our use both of panel methods and of dynamic considerations in our estimation.

First, for many developing countries data that span a long period of time are simply not available, which normally prevents the application of robust time series methods for these countries. However, panel methods - whether static or dynamic - overcome this data hurdle by providing more degrees of freedom in the estimation of the currency demand equation, which 
allows us to include many countries that previously had to be omitted from the analysis due to the lack of sufficient time series data. Relatedly, by accounting for the heterogeneity of countries using panel methods, we are able to include both developed and developing countries in the same regression, again increasing the degrees of freedom.

Second, the use of panel data - again, whether static or dynamic - allows us to include in the currency demand equation important variables that are not typically available in time series modeling because such variables do not have much intra-country variation over time. Time series estimation methods cannot adequately pick up the effect of such variables on currency demand, and these variables must be excluded from the estimation, leading to the standard omitted variable problem and misspecification bias. However, panel methods overcome this problem by accounting for cross-sectional variation. In our study, for example, the use of panel data methods allows us to include measures that reflect the enforcement efforts of the tax administration. Enforcement measures emerge from all theoretical analyses of the standard tax evasion decisions of individuals, beginning with Allingham and Sandmo (1972), but they have been omitted in all previous studies. We are able to proxy for them with institutional quality indicators with our panel data methods.

Third, our incorporation of dynamic methods allows us to account for the persistence of currency demand as it evolves over time. Katircioglu, Fethi, and Fethi (2004) and Simanjuntak (2008) argue that previous time series studies of the currency demand method have used simple (static) estimation methods that almost certainly result in spurious regressions due to the presence of a unit root in the variables. While cointegration techniques might help in the case of single country regressions, Pierce and Snell (1995) argue that the span of the data is crucial for the power of such tests. They also suggest that expanding the time horizon risks including 
possible structural breaks of the long-term data, so that it is desirable to draw the data from cross-sectional panels. Given that our data can be characterized as one in which we have a large number of observations (e.g., countries) and a relatively short time span, these considerations suggest that meaningful unit root tests cannot be done for our data. However, the econometric method we employ uses the variables in their difference form, and so any variable that is integrated of degree one is made stationary with such differencing. It is especially here where our use of dynamic panel methods allows us to address the various econometric issues.

Accordingly, we argue that dynamic panel data methods are most appropriate for estimating the currency demand equation, especially as currency demand evolves over time. ${ }^{2}$ These methods allow us to present a comprehensive set of estimates of the size of shadow economy across many countries and many years, using the currency demand method. The absence of shadow economy measures for individual countries (especially developing countries) over a long time period has limited the study of the causes and consequences of shadow economy. Our study relaxes this constraint. With our estimates of the shadow economy for a long panel of countries, it is now possible to reexamine previous studies of the relationships between the shadow economy and various macroeconomic aggregates using panel data methods instead of being forced to rely on simple cross-section relationships.

Our results indicate a substantial shadow economy across countries, ranging from 10 to 86 percent of GDP over the entire period and with some tendency to grow over time. We also find that the shadow economy varies significantly by country income group. The mean shadow economy is about 17 percent of GDP for OECD countries, 24 percent for non-OECD high income countries, 33 percent for upper middle income countries, 37 percent for lower middle income countries, and 38 percent for lower income countries. 


\section{The Currency Demand Method}

The currency demand method is based on the work of Cagan (1958), who estimated the determinants of the ratio of currency to "broad money" (or M2) for the United States. His estimates showed that the key driving factors in the demand for currency were per capita income, the interest rate, and, importantly, the tax rate. Building on this initial work, Gutmann (1977) actually calculated the shadow economy of the U.S., using the assumption that a higher tax rate was the main cause of the post-war increase in currency holdings. However, he did not empirically estimate the currency demand equation. It took Tanzi $(1980,1983)$ to extend the Cagan (1958) work, by estimating the currency demand and then using these results to generate estimates of the size of the shadow economy in the United States for the period 1930 to 1980.

The currency demand approach is one of the most popular methods for estimating shadow economy. Following Tanzi $(1980,1983)$, subsequent studies have applied the basic method to other countries, including Matthews (1982) and Bhattacharyya $(1990,1999)$ for the U.K., Klovland (1984) for Norway and Sweden, Bajada (1999) for Australia, Giles (1999a, 1999b) for New Zealand, Schneider $(1997,2002)$ and Johnson, Kaufmann and Zoido-Lobato'n (1998) for OECD countries, Williams and Windebank (1995) for EU countries and Giles and Tedds (2002) for Canada. These studies all point to significant amounts of shadow economic activities in these countries, and have broadened our understanding on the causes and extent of shadow economies, especially in higher income countries.

It should be noted that the currency demand approach has been subject to several criticisms (Schneider and Enste, 2000; Thomas, 1992, 1999). First, the approach assumes that all transactions in the shadow economy are paid in cash, so that the method may not capture all 
shadow economy activities. Second, many studies assume the same velocity of money in the official and shadow economies. As shown recently by Ahumada, Alvaredo, and Canavese (2007, 2008), the velocity of currency in the underground economy depends on the income elasticity of cash demand, so that the assumption of equal velocity of currency in the shadow and official economy holds only when this elasticity is unity. ${ }^{3}$ Third, most studies include only one cause of the shadow economy, such as high taxes. There are of course other factors that affect the size of shadow economy, such as labor market regulations, the complexity of tax system, and welfare benefits. Shima (2005) and Carolina and Pau (2007) include some of these factors in their estimation of shadow economy of Norway and Netherlands Antilles, respectively. We also relax this assumption, but at the same time we focus on the most important factors driving the shadow economy for which data are available for many countries in our sample. Of perhaps most importance, we include enforcement strength of the tax administration, as discussed later. ${ }^{4}$

Our basic approach builds upon the Tanzi $(1980,1983)$ currency demand method to estimate the size of shadow economy, but we apply modern dynamic panel methods in the estimation. ${ }^{5}$ This method starts by estimating an equation with the ratio of currency (C) to broadly defined money (M2) as the dependent variable, as a function of several other explanatory variables that measure incentives for tax evasion and non-tax evasion activities. The main assumption in the currency demand approach is that shadow economic activities are the direct result of weak enforcement and high taxes, and that currency instead of demand deposits can be used for undertaking such transactions because currency is anonymous and enables the user to avoid being traced.

Following Cagan (1958), Tanzi (1980, 1983), and some others, we include the tax rate, real per capita income, and the interest rate on time deposits as explanatory variables. To these, 
we add the inflation rate, the degree of urbanization, and, importantly, the enforcement strength of the tax administration, as discussed in more detail later. The general form of the estimated equation is:

$$
\ln (C / M 2)_{i t}=\beta X_{i t}+u_{i t},
$$

where $t$ indexes years and $u_{t}$ is the disturbance term; $\ln (C / M 2)$ is the logarithm of the ratio of currency $C$ to $M 2, X$ is a vector of tax evasion and non-tax evasion factors, and $\beta$ is the vector of corresponding coefficients.

A first important factor is the tax rate. We expect the tax rate to have a positive impact on the currency ratio. Since currency provides anonymity, individuals who wish to evade taxes will use more currency and less demand deposits. A higher tax rate increases the gain from (successful) tax evasion, and so we expect that a higher tax rate will increase the currency ratio.

Relatedly, inflation is another potentially relevant factor and one that many previous studies have omitted in the currency demand analysis. When tax systems are not indexed, higher inflation creates tax bracket creep and increases the tax liabilities of taxpayers, increasing the incentives for greater tax evasion. Fishburn (1981) argues that one way inflation can affect the decision to evade taxes is that inflation erodes the real value of a given level of nominal disposable income, which gives taxpayers the incentive to evade more taxes to restore their purchasing power. Crane and Nourzad (1986) test the effect of inflation on aggregate tax evasion in the United States for the period 1947-1981, and they find that tax evasion is positively related to the inflation rate. However, inflation can also have a negative effect on the currency ratio if individuals substitute currency for interest-bearing assets to prevent the inflationary erosion of the purchasing power of their wealth by inflation. We include inflation as a tax evasion factor because inflation is a taxation tool many governments use to make up for the tax 
revenue they cannot collect because of tax evasion; that is, since the tax revenue to GDP ratio is an imperfect measure of the actual tax rate imposed by the government because of tax evasion, the inflation rate may convey information about the effective tax rate. For example, many developing countries have a lower tax to GDP ratio not because they impose lower tax rates but because they exhibit higher tax evasion. The response is to print money to make up for the shortfall, which results in higher inflation as an implicit tax on individuals and firms.

Similarly, the interest rate is the opportunity cost of holding currency rather than interest bearing assets such as time and saving deposits. A higher interest rate will lead to a lower demand for currency and a lower currency ratio.

Cagan (1958) argues that higher income will decrease the currency ratio because demand deposits are superior assets compared to currency. Also, in a cross-country context, economic development (as proxied by per capita income) will lead to a reduced use of currency and to an increased use of checks, implying a negative relationship between per capita income and the C/M2 ratio.

Although he does not empirically test for it, Cagan (1958) argues that the degree of urbanization is a potential determinant of the currency ratio. Urbanization forces people to trade where they are not known, which reduces the use of checks and increases the use of currency. However, the use of checks is typically lower in rural areas than in cities, which has the opposite effect on the currency ratio. The net effect of the degree of urbanization on the currency ratio is ambiguous.

A particularly crucial factor that has been overlooked in all previous studies is the enforcement strength of the tax administration. There is most likely a positive relationship between higher tax enforcement capability of the tax administration and the level of the tax 
evasion. ${ }^{6}$ The omission of any measure of or proxy for tax enforcement strength when estimating the currency equation is likely to lead to the misspecification bias in the estimated relationship. We discuss our proxy for enforcement in the next section.

Once equation (1) is estimated, we use the resulting estimates to calculate the yearly shadow economy. There are several steps here. First, we calculate the predicted value of currency with all factors (tax evasion and non-tax evasion) included; this value is denoted $C^{*}$. Second, we calculate the predicted value of currency $\left(C^{*}\right)$ assuming no tax evasion, by setting the tax rate and inflation rate at the minimum values (zero) and the enforcement proxy at its maximum value. ${ }^{7}$ Third, we subtract $C^{* *}$ from $C^{*}$, to give the stock of currency attributed to tax evasion. Fourth, we multiply this stock of currency used for tax evasion purposes by the velocity of money, to yield the amount of income supported by this stock of illegal currency. ${ }^{8}$ Finally, we divide this quantity by GDP, to express the shadow economy as the percentage of the official economy.

\section{Estimation Methodology and Data}

\subsection{Estimation Methodology}

Due to the heterogeneity of countries in the sample, we estimate equation (1) using panel data techniques. By accounting for the heterogeneity of countries using panel data estimation methods, we justify the inclusion of OECD and non-OECD countries in the same regression, thereby expanding the degrees of freedom in our estimation. Panel methods also allow us to include relevant variables that are not typically used due to lack of intra-country variation over time. Finally, we introduce dynamics to equation (1) since there may be persistence in the data 
as individuals adjust the level of their currency demand slowly over time toward their desired demand. For all of these reasons, we use dynamic panel estimation methods.

With the introduction of heterogeneity, additional variables, and dynamics, we rewrite equation (1) as:

$$
z_{i t}=\alpha z_{i, t-1}+\beta X_{i t}+\eta_{i}+u_{i t},
$$

where $z_{\mathrm{it}}$ is the logarithm of currency ratio in country $i$ at time $t, z_{\mathrm{i},-1}$ is the lagged value of the currency ratio, and $\mathrm{X}_{\mathrm{it}}$ is a vector of explanatory variables that include tax evasion and non-tax evasion factors that potentially determine the currency ratio, $\eta_{\mathrm{i}}$ is the country fixed effect, and $u_{i t}$ is the error term that is assumed to be white noise. Because we use annual data, we expect that an AR(1) model will capture all the autocorrelation over time. It is also possible that there might be some degree of spatial dependence across countries, but it seems unlikely that such spatial effects will play much role in the determination of shadow economies. We include time dummies to capture any shock to the currency demand that is common to all countries.

By taking the first difference in the dynamic equation (2), we eliminate the countryspecific effect, generating the following equation:

$$
\mathrm{z}_{\mathrm{it}}-\mathrm{z}_{\mathrm{i}, \mathrm{t}-1}=\alpha\left(\mathrm{z}_{\mathrm{i}, \mathrm{t}-1}-\mathrm{z}_{\mathrm{i}, \mathrm{t}-2}\right)+\left(\mathrm{X}_{\mathrm{it}}-\mathrm{X}_{\mathrm{i}, \mathrm{t}-1}\right)^{\prime} \beta+\left(\mathrm{u}_{\mathrm{it}}-\mathrm{u}_{\mathrm{i}, \mathrm{t}-1}\right) .
$$

Note, however, that the difference lag of the currency ratio $\left(z_{i, t-1}-z_{i, t-2}\right)$ is correlated with the error term, or $\Delta u_{i t}=u_{i t}-u_{i, t-1}$ because $z_{i, t-1}$ and $u_{i, t-1}$ are now both on the right hand side of the transformed equation. Thus, while differencing eliminates the unobserved fixed effect (and also has the benefit of making variables with a unit root stationary), it introduces an endogeneity problem that must be dealt with. There is also an endogeneity problem because $X_{\mathrm{it}}$ may contain potentially endogenous variables, especially the tax rate. Our proxy for the tax burden is 
calculated as the ratio of total tax revenues to GDP. The source of endogeneity is the joint determination of the tax rate and the level of tax evasion as measured by the currency ratio.

To deal with these endogeneity issues, we use the Arellano and Bond (1991) dynamic panel data method because the traditional panel data methods (e.g., Pooled OLS estimation, Fixed Effects estimation, Random Effects estimation) are no longer consistent under such endogeneity. The Arellano and Bond (1991) method is based on a GMM estimator that uses a broad set of lagged levels of the endogenous variables as instruments for the differenced equation. Unlike other instrumental variable estimators like 2SLS that generally require "external" instruments, the GMM method uses "internal" instruments for the differenced lagged dependent variable as well as for the other potentially endogenous regressors of the model. Thus, the GMM method is particularly well suited for our study because it is difficult to find an external instrument for the tax rate. Nevertheless, for purposes of comparison, we use the traditional panel data methods as well.

Under the assumption of no serial correlation of errors ( $E u_{i t} u_{i, t-1}=0$ ), the moment conditions that furnish the appropriate instruments for the differenced lagged dependent variable and the other endogenous regressors are:

$$
\begin{aligned}
& \mathrm{E}\left(\mathrm{z}_{\mathrm{it}-\mathrm{s}} \Delta \mathrm{u}_{\mathrm{it}}\right)=0 \text { for } t=3, \ldots, T \text { and } s \geq 2 \\
& \mathrm{E}\left(\mathrm{X}_{\mathrm{it}-\mathrm{s}} \Delta \mathrm{u}_{\mathrm{it}}\right)=0 \text { for } t=3, \ldots, T \text { and } s \geq 2 .
\end{aligned}
$$

When these two moment conditions (and an additional standard initial condition assumption $E\left(z_{i l} u_{i t}\right)=0$ hold$)$, one can use the lagged levels of the endogenous variables as instruments in the first difference equation. See Blundell and Bond (1998) for a detailed discussion. We call this "GMM Difference" estimator, which consists of equation (3) plus the moment conditions in equations (4) and (5). 
However, when the dependent variable is persistent (or $\alpha$ in equation (3) is close to 1), its lagged levels are weakly correlated with subsequent first differences, and they become poor instruments for the endogenous variables. In such a case, Arellano and Bover (1995) propose an estimator that makes use of additional information in levels. Their procedure involves the joint estimation of an equation in levels (or basically equation (2) above) along with the difference equation, in which the endogenous variables in the former equation are instrumented by their lagged difference. This alternative estimator, which is referred to as the "GMM System" estimator, combines the equation in the first difference and the equation in the levels. This estimator introduces an additional $T-2$ moment conditions given by:

$$
\begin{aligned}
& E\left[\left(\eta_{i}+u_{i t}\right) \Delta z_{i t-1}\right]=0 \\
& E\left[\left(\eta_{i}+u_{i t}\right) \Delta X_{i t-1}\right]=0 .
\end{aligned}
$$

In summary, the GMM System estimator uses the moment conditions (4) and (5) (as in the GMM Difference estimator) and also imposes the additional moment conditions (6) and (7), in order to obtain consistent estimates of the coefficients of the currency equation. Because of these additional moment conditions, it is important to remember that the GMM System estimator is based on more restrictive assumptions. If these assumptions do not in fact hold, the GMM System estimator leads only to "instrument proliferation" (Roodman, 2009), in which case the numerous instruments can over-fit the instrumented variables, can fail to expunge the endogenous components, and can bias the resulting coefficient estimates.

Thus, the choice between the GMM System estimator and the GMM Difference estimator is based on the results of various specification tests. In this regard, we use the "Hansen test" of over-identifying restrictions to test the joint validity of the instruments used in a regression (Hansen, 1982). We also use the "difference-in-Hansen test" for testing the validity of a subset 
of instruments. In particular, we test whether our data support the use of System GMM over the difference GMM estimator. For the joint validity of instruments, the null hypothesis is that the instruments are exogenous or orthogonal to the error term, and under the null, the test statistic is distributed $\chi_{(L-k)}^{2}$, where $L$ is the number of instruments and $k$ is the number of parameters in the model. For the difference-in-Hansen test, the test statistic is also distributed $\chi_{(m)}^{2}$, where $m$ is the number of restrictions given by the number of instruments in the subset being tested.

Also, recall that either GMM estimator yields consistent estimates only if the errors in the level equation are white noise. To test whether the errors in the level equation are white noise, we use the Arellano and Bond (1991) test for second-order autocorrelation in the difference equation (3). The existence of first-order autocorrelation in the difference equation conveys no information about the existence of correlation of errors in the level equation. The null of this test is that there is no second-order autocorrelation in the difference equation.

\subsection{Data}

Our sample includes OECD and non-OECD countries for the period 1984 to 2006. The sample period is limited by the availability of data for the variables measuring enforcement strength, which all start in 1984. Thus, there is nothing unique about the first observation for the countries in the sample, and it can be assumed that the initial condition restriction necessary for the moment condition to be valid in fact holds. Since there are missing observations for some countries, we have an unbalanced panel. ${ }^{9}$ The countries included in the sample are reported in Table 1.

Data for the currency $C$, broad money $M 2$, and the interest rate $(r)$ are drawn from International Monetary Fund's International Financial Statistics CD-ROM (2008). Currency C is defined as the notes and coins held outside banks, and $M 2$ consists of money plus quasi 
money; the interest rate is the bank deposit rate. Data for the inflation rate $(\pi)$, the degree of urbanization (Urban), and per capita income $(Y$ ) are drawn from the World Development Indicators CD-ROM (2007). Urbanization is measured by the percentage of population living in urban areas. Per capita income is GDP (in constant 2000 U.S. dollars) divided by population. Inflation is defined as the percentage change in the consumer price index.

The driving factors in the shadow economy are the tax rate, the enforcement variable, and the inflation rate (if it reflects tax bracket creep). The tax rate $(\tau)$ is defined as the total tax burden (given by total tax revenues) expressed as a percentage of GDP. ${ }^{10}$ This measure is mainly drawn from World Development Indicators CD-ROM (2007), although we have used the CIA economic unit online data to fill in some of the missing observations.

The enforcement variable $(E)$ is one for which a good measure has always been difficult to generate. In theory, enforcement is measured by some combination of the likelihood of detection of tax evaders and the severity of penalties imposed on them; the probability of detection of violators could be measured by the number of people audited per total number of taxpayers, and the penalty rate could be measured by the statutory rate at which the government penalizes the violators. Unfortunately, such data are not available for most countries; further, they cannot measure the zeal, efficiency, and effectiveness with which tax laws are actually implemented. A higher audit rate does not necessarily translate into higher detection and punishment if people caught are not actually penalized due to corruption in the tax administration. Similarly, a higher statutory penalty rate decreed by law does not necessarily imply a higher actual penalty, for similar reasons.

We proxy enforcement strength by two institutional quality indicators, or the scores of Quality of Bureaucracy and the Rule of Law, as drawn from the International Country Risk 
Guide (ICRG) of the Political Risk Services (2006). Our proxy $E$ is constructed as the product of the scores of the Quality of Bureaucracy and the Rule of Law, and equals $E=(1+$ Rule of Law)*(1+ Quality of Bureaucracy). The Quality of Bureaucracy score ranges from 0 to 6, while Rule of Law varies from 0 to 4 . For both of these variables, a higher score indicates higher institutional quality and hence higher enforcement strength. We recognize that our proxies for enforcement strength are imperfect indicators, and may well measure other aspects of the quality of governance (and its perception by individuals) that are not specific to tax administration, such as tax morale and trust in government (Torgler and Schneider, 2009). However, if we think of institutional quality as a reflection of governmental efficiency, then efficiency in one domain of the government is likely to be reflected in other domains. Likewise, an improvement of efficiency in one of the functions of government generally will spill over to the other functions. Indeed, when taxpayers contemplate underreporting income, they seem likely to consider the efficiency or strength of the bureaucracy in fighting tax evasion. In a corrupt tax administration, it would be easy to get away with evasion, even if caught, by bribing the tax collector. Therefore, we believe that institutional quality indicators can adequately proxy for the level of efficiency of the tax administration.

Table 2 reports the descriptive statistics for the variables. These statistics demonstrate the incredible diversity of cross-country variation in the currency ratio (as well as the other variables) for the countries, ranging from 1 to 84 percent. ${ }^{11}$ Table 3 reports the correlation matrix for the variables. The correlation results show that there is little collinearity between the explanatory variables.

\section{Results}


In this section we estimate the currency equation, and we also calculate the shadow economy based on the estimation results. We report in Table 4 various estimation results, focusing on the two variants on dynamic panel data methods (GMM System estimates and GMM Difference estimates). To facilitate comparison, we report results for a common core set of variables: the tax rate $\tau$, enforcement $E$, the inflation rate $\pi$, per capita income $Y$, the interest rate $r$, and urbanization Urban. We also include in all specifications the interaction of the tax rate and a dummy variable $O E C D$ (equal to 1 for OECD countries and 0 otherwise) to account for the possibility that the tax elasticity of currency demand may be different for OECD and non-OECD countries. ${ }^{12}$ We include year dummies in all specifications. Note that we have estimated a very large number of alternative specifications, across all estimation methods, with little change in our results. All results are available upon request.

We start with the traditional panel data methods: Pooled OLS, Fixed Effects, and Random Effects methods. All three estimation methods are broadly similar, with generally insignificant and sometimes counterintuitive coefficient estimates. These disappointing results are likely due to the endogeneity problems discussed earlier, especially for our measure of the tax rate. These results are not reported, but are available upon request.

Accordingly, we focus on the results of the Arellano and Bond (1991) and Arellano and Bover (1995) dynamic panel data estimators, reporting results for both the GMM System (Table 4 (a)) and the GMM Difference (Table 4 (b)) estimators.

As pointed out by Roodman (2009), instrument proliferation is an issue to watch in both the GMM System and the GMM Difference estimators. A standard rule of thumb for these estimators is that the number of instruments must be less than the number of groups (or countries in our case). In our estimations, the differenced tax rate is instrumented by its first lag in all 
specifications. For the lagged dependent variable, we increase the number of instruments one at a time; that is, in the first specification, the differenced lagged dependent variable is instrumented by its first lag in level, in the second specification by its first and second lags in levels, and so on. The purpose of such variation is to increase efficiency in the estimation and at the same time to control for the problem of instrument proliferation.

However, for the GMM System estimation, using more than the first lag as instruments pushes the number of instruments to 129 compared to 111 countries. Thus, we use only the first lag in the GMM System estimation, resulting in 109 instruments (Table 4(a)). While the Hansen test of joint over-identifying restriction shows that the instruments are jointly valid, the difference-in-Hansen test for the validity of instruments used in the level equation indicates that the instruments are not in fact valid (p-value of 0.098). ${ }^{13}$ In such a case, using the GMM Difference estimator is preferred to using the GMM System estimator, at least if the former passes the Hansen specification tests, as it in fact does.

Accordingly, our preferred estimates are for the GMM Difference estimator, as reported in Table 4(b). Three specifications, differing only by the number of instruments, are reported.

Turning to these GMM Difference results, it is necessary to check whether the assumptions for using the dynamic panel data model are met. As discussed earlier, the use of the dynamic panel model requires (among other things) that the error term of the dynamic equation in levels be white noise. This implies that, while the errors of the equation in first differences might have first-order autocorrelation by construction, second-order autocorrelation must be absent. Therefore, the first specification test requires that we test for the existence or absence of second-order autocorrelation. Specifically, we test the null hypothesis that there is no secondorder autocorrelation in the differenced equation. The Arellano and Bond (1991) test results for 
$\mathrm{AR}(2)$ in first differences indicate a p-value of greater than 0.05 in all regressions in Table 4(b), which demonstrates that the null is not rejected at the 5 percent significance level. We conclude that there is no evidence for second-order autocorrelation and so that our assumption of no serial correlation of errors in equation (2) is supported.

To test the validity of the instruments, we use the Hansen test of over-identifying restrictions. The endogenous variables are the lagged value of the dependent variable and the tax rate. The reported p-values of the Hansen test of joint validity of instruments are greater than 0.05 for all specifications in Table 4(b), which shows that the null cannot be rejected at 5 percent significance level. This result supports the validity of the lagged values of the explanatory variables as instruments.

Each specification in Table 4(b) passes the Hansen and the Arellano and Bond (1991) tests, and the coefficient estimates are very similar across these specifications. Even so, specification (3) gives the most efficient estimates, as seen from the standard errors of coefficient estimates. Therefore we focus on specification (3) in the remaining discussion. ${ }^{14}$

The estimate on the tax rate is positive as expected. The interaction of OECD and the tax rate is also significant and with the expected sign, showing that the currency demand tax rate elasticity is lower in OECD countries than in the other countries. The estimate on the enforcement effort is also significant and negative as expected. Given these results, it can be concluded that countries with high tax rates and weak enforcement capabilities have a higher currency ratio, which implies greater tax evasion and a larger shadow economy. A higher inflation rate increases currency demand, perhaps because higher inflation leads to tax bracket creep and, as taxpayers move into higher tax brackets and their tax liabilities increase, they attempt to evade more via greater use of currency. 
As for other variables, the coefficient on income per capita is negative and significant, as expected, which implies that economic development as reflected in higher per capita income generates a lower currency to M2 ratio, perhaps due to increased financial sophistication with development. The coefficient estimate on the interest rate is significant but positive. The coefficient estimate on urbanization is significant and positive as expected.

Having estimated the currency equation, it is now possible to use these estimated coefficients to calculate the size of the shadow economy by year for each country in the sample. We use specification (3) of Table 4(b) for our calculations of the underground economy. ${ }^{15}$ Applying the procedure described earlier, we calculate each country's shadow economy for every year over the entire period 1984 to 2006 . The detailed results of these calculations are reported in the Appendix Table. These estimates are summarized in Table 5 and in Figure 1, both of which report summary statistics for the estimated size of shadow economy for the entire 1984-2006 period by country income group. The results show a substantial shadow economy in most countries during this period, as well as a wide variation of its magnitude across countries. The mean shadow economy for the entire sample is about 32 percent of GDP with a standard deviation of about 12 percent. Table 5 shows that the mean value of shadow economy declines as income increases. The estimated shadow economy as a percentage of GDP is about 38 percent for lower income countries, 37 for lower middle income countries, 33 percent for upper middle income countries, 24 percent for the non-OECD high income countries, and 17 percent for OECD countries.

To provide more insight on the evolution of shadow economy by country, we average a country's shadow economy over two periods, for the early period 1990-1997 and the more recent 
period 1998-2006. The results of this exercise are given in Figure 2, Panel (a) to Panel (e), based again on country income group classifications.

For the low income country group, several countries experienced an increase in the shadow economy as a percentage of GDP: Burkina Faso, Cameroon, Congo Republic, Cote d'Ivoire, Ghana, Kenya, Madagascar, Nigeria, Papua New Guinea, Senegal, Sierra Leone, Togo, Yemen Republic, and Zimbabwe. Lower middle income countries that experienced an increase in the shadow economy include Albania, China, Colombia, Dominican Republic, Ecuador, Jamaica, Jordan, Paraguay, and Thailand. Upper middle income countries here include Botswana, Costa Rica, Gabon, Mexico, South Africa, Turkey, and Venezuela. For high income non-OECD countries, the shadow economy increased for Bahrain, while in the OECD countries Australia, France, Greece, Italy, Japan, Korea, Switzerland showed an increase, although for some of these OECD countries the change is very small.

We also compare our estimates to an important study done by Schneider (2005). He estimates shadow economies for 110 countries for the years 1990, 1995, 2000 using the "Multiple Indicators Multiple Causes" (MIMIC) method. The MIMIC method first estimates various indices of the shadow economy using multiple indicators and multiple causes of the shadow economy; the indices of the shadow economy are then multiplied by a scaling factor to generate the actual shadow economy figures. The scaling factor is usually derived from other studies of shadow economy estimation methods, such as the currency method; hence the size of the shadow economy in the MIMIC method is heavily dependent on the choice of this scaling factor.

Table 6 reports the summary statistics of Schneider's (2005) estimates and our estimates for the years 1990, 1995, and 2000, in which our shadow estimates are averaged for these years 
to create a single observation per country. To make a meaningful comparison, Table 5 reports only the results for those countries that are included in both studies. The average shadow economy estimates of the two studies are quite similar. The mean value of Schneider's (2005) shadow economy estimates is about 29 percent of GDP, compared to ours of 31 percent. The standard deviations are also quite similar, 12.6 percent of his estimates compared to 9.7 percent of our estimates. The comparison of the shadow economy estimates of both studies is also presented in Figure 3, which shows a scatter plot and an upward slopping linear fit of the estimates. The fitted line demonstrates a positive correlation between the two estimates, with an $\mathrm{R}^{2}$ of 0.46 . Given the difference in the method of estimating the shadow economy, such an $\mathrm{R}^{2}$ is a good affirmation that the estimates from both studies are similar.

Even so, there are some significant differences in the estimates, especially by specific country. For example, we find Algeria, Mali, Nicaragua, Peru, and Poland to be the top five countries with the highest shadow economy for the period, while Schneider (2005) finds Azerbaijan, Bolivia, Nigeria, Peru, Ukraine, and Zimbabwe to have the highest shadow economy in the same period. These differences are likely due to the fact that each study uses different variables to explain the shadow economy aside of course from the tax rate, which is common to both approaches. In particular, we use a measure of enforcement strength of tax administration as a cause of shadow economy. Our inclusion of enforcement parameters gives the advantage of having shadow economy estimates that are consistent with the theory of tax evasion. Each study also uses a somewhat different definition of the shadow economy. In particular, our definition allows for the inclusion of illegal activities.

\section{Conclusions}


Our study estimates the shadow economy for a panel of countries using the currency demand method, using the Arellano and Bond (1991) GMM dynamic panel data model. An important contribution of our work is that, unlike all previous work, we are able to include (along with the tax rate) a measure of tax administration enforcement strength as a driving factor in tax evasion. We are also able to estimate the shadow economy with a consistent estimation method for a wide range of countries over an extended period and to address econometric issues that typically arise in dynamic panel data estimation methods.

We find that the currency to M2 ratio tends to be higher the higher the economic return from underreporting (as given by the tax rate), the weaker the enforcement capacity of the tax administration, and the higher the inflation rate. We also find that the currency ratio is affected in predictable ways by non-tax evasion factors such as per capita income, the interest rate, and the degree of urbanization. From the estimated currency demand equation, we estimate the yearly shadow economy for each country in our sample for all years 1984 to 2006 . Our calculations show that the size of the shadow economy as a percent of GDP is substantial, with wide variation across the countries. On average, our estimates indicate that the mean shadow economy is about 36 percent with a standard deviation of 15 percent. We also find that the estimated size of the shadow economy varies significantly by income level, with lower income countries having a larger shadow economy. We are hopeful that these estimates will prove useful to researchers in their examination of the causes and the consequences of the shadow economy. 
Appendix

Shadow Economy Estimates (as percent of GDP), All Countries, 1984-2006

\begin{tabular}{|c|c|c|c|c|c|c|c|c|c|c|c|c|c|c|c|c|c|c|c|c|c|c|c|}
\hline Countries & 1984 & 1985 & 1986 & 1987 & 1988 & 1989 & 1990 & 1991 & 1992 & 1993 & 1994 & 1995 & 1996 & 1997 & 1998 & 1999 & 2000 & 2001 & 2002 & 2003 & 2004 & 2005 & 2006 \\
\hline Albania & & & & & & & & & & & & 32.1 & 30.8 & 36.2 & 37.8 & 39.0 & 41.3 & 41.9 & 40.0 & 37.7 & 38.0 & 37.3 & 36.3 \\
\hline Algeria & & & & & & & & & & & 49.3 & 50.9 & 51.8 & 48.8 & 44.1 & 46.0 & 53.7 & 49.9 & 49.4 & 46.4 & 44.1 & 45.0 & 45.8 \\
\hline Argentina & 46.6 & 52.3 & 36.1 & 37.0 & 40.2 & 68.2 & 64.3 & 36.2 & 30.4 & 28.8 & 26.6 & 25.5 & 24.6 & 23.3 & 21.5 & 21.3 & 21.7 & 22.0 & 27.1 & 33.4 & 29.3 & 29.9 & 33.4 \\
\hline Armenia & & & & & & & & & & & & & & & & & & & 37.0 & 37.1 & 37.2 & 37.1 & 37.3 \\
\hline Australia & 13.9 & 14.5 & 14.7 & 14.6 & 14.5 & 14.6 & 14.9 & 14.7 & 13.9 & 13.8 & 13.8 & 14.2 & 14.4 & 14.3 & 14.4 & 14.2 & 14.6 & 15.0 & 14.6 & 14.8 & 14.8 & 15.1 & 15.8 \\
\hline Austria & 18.6 & 18.2 & 18.1 & 18.0 & 17.6 & 16.9 & 16.9 & 17.0 & 17.4 & 17.5 & 17.4 & 13.2 & 13.4 & 13.8 & 13.8 & 13.7 & 13.7 & 14.2 & 14.1 & 14.0 & 14.0 & 13.9 & 13.8 \\
\hline Azerbaijan & & & & & & & & & & & & & & & & 31.9 & 33.1 & 33.4 & 33.9 & 34.1 & 34.9 & 36.6 & 37.1 \\
\hline Bahrain & 19.4 & 19.6 & 21.1 & 19.9 & 19.6 & 20.2 & 18.0 & 17.9 & 16.0 & 14.7 & 14.1 & 15.9 & 19.1 & 19.3 & 19.6 & 19.0 & 18.4 & 18.7 & 18.3 & 18.2 & 19.2 & 18.7 & 18.7 \\
\hline Bangladesh & 48.7 & 50.0 & 49.0 & 49.3 & 49.3 & 50.2 & 50.2 & 50.3 & 50.2 & 34.1 & 30.9 & 31.2 & 30.8 & 28.6 & 25.3 & 26.0 & 29.3 & 29.9 & 32.5 & 34.9 & 36.0 & 30.8 & 28.7 \\
\hline Belarus & & & & & & & & & & & & & & & 40.6 & 48.8 & 44.5 & 38.8 & 36.5 & 38.6 & 38.5 & 39.5 & 40.9 \\
\hline Bolivia & & 86.3 & 67.0 & 53.5 & 52.0 & 52.5 & 52.9 & 54.0 & 49.5 & 42.5 & 38.1 & 34.8 & 38.1 & 35.4 & 32.8 & 31.5 & 31.6 & 31.3 & 30.7 & 30.7 & 32.4 & 33.6 & 34.2 \\
\hline Botswana & & 29.5 & 34.3 & 35.1 & 32.7 & 30.0 & 33.3 & 31.9 & 36.6 & 34.4 & 31.0 & 28.8 & 28.7 & 39.0 & 39.3 & 38.4 & 35.9 & 34.3 & 35.8 & 36.3 & 35.6 & 34.1 & 33.2 \\
\hline Brazil & 36.1 & 36.2 & 34.3 & 36.1 & 44.5 & 54.4 & 62.4 & 36.2 & 44.7 & 55.5 & 60.6 & 28.5 & 25.8 & 27.6 & 33.2 & 33.5 & 33.9 & 34.0 & 35.6 & 37.5 & 34.4 & 33.0 & 34.6 \\
\hline Bulgaria & & & & & 46.2 & 46.6 & 35.1 & 46.3 & 33.3 & 31.1 & 36.9 & 34.3 & 34.1 & 58.1 & 33.2 & 31.7 & 32.5 & 31.6 & 31.0 & 32.4 & 35.0 & 35.8 & 37.6 \\
\hline Burkina Faso & & 26.6 & 27.1 & 27.4 & 27.2 & 26.4 & 29.6 & 33.6 & 31.3 & 30.0 & 30.0 & 29.2 & 29.4 & 29.5 & 29.9 & 30.0 & 30.3 & 31.0 & 32.4 & 33.0 & 33.3 & 33.2 & 33.0 \\
\hline Cameroon & 37.4 & 33.7 & 30.0 & 28.3 & 28.7 & 29.3 & 24.3 & 24.7 & 27.9 & 26.5 & 26.0 & 23.9 & 24.7 & 27.9 & 34.6 & 34.5 & 35.8 & 37.8 & 37.7 & 37.3 & 37.4 & 37.4 & 35.5 \\
\hline Canada & 13.0 & 12.9 & 13.2 & 13.4 & 13.3 & 13.5 & 12.5 & 12.6 & 12.2 & 12.0 & 12.0 & 12.1 & 12.2 & 12.5 & 12.4 & 12.4 & 12.4 & 12.3 & 12.0 & 12.1 & 12.1 & 12.2 & 12.1 \\
\hline Chile & 34.2 & 36.2 & 35.4 & 34.3 & 31.8 & 31.8 & 31.8 & 33.1 & 33.3 & 33.7 & 31.2 & 30.0 & 29.4 & 26.9 & 26.7 & 25.0 & 24.8 & 24.7 & 24.8 & 24.4 & 24.8 & 26.2 & 27.7 \\
\hline China & & & & & & & 23.3 & 23.1 & 18.3 & 17.9 & 20.9 & 17.7 & 17.5 & 19.5 & 19.5 & 19.9 & 21.0 & 23.2 & 22.8 & 23.0 & 23.4 & 23.2 & 23.1 \\
\hline Colombia & 29.9 & 35.2 & 35.4 & 36.1 & 36.6 & 36.5 & 35.4 & 37.0 & 37.0 & 37.2 & 30.3 & 29.1 & 29.4 & 33.7 & 33.5 & 33.0 & 38.5 & 40.7 & 39.4 & 40.7 & 39.9 & 42.2 & 39.3 \\
\hline Congo, Dem. Rep. & 55.2 & 51.7 & 44.7 & 45.7 & 46.8 & 49.9 & 47.3 & 77.1 & 85.5 & 76.2 & 73.0 & 57.7 & 56.4 & 48.0 & 46.4 & 60.4 & 67.5 & 62.3 & 52.2 & 50.5 & 51.8 & 53.1 & 52.1 \\
\hline Congo, Republic & & & & & & & & & 41.1 & 39.1 & 36.6 & 35.1 & 35.0 & 23.6 & 42.4 & 41.2 & 34.8 & 36.6 & 36.1 & 36.2 & 35.5 & 34.3 & 34.4 \\
\hline Costa Rica & 33.9 & 33.1 & 32.9 & 35.3 & 35.6 & 34.9 & 26.5 & 27.5 & 26.5 & 27.4 & 27.3 & 28.3 & 28.3 & 28.0 & 27.9 & 27.4 & 27.6 & 28.4 & 28.3 & 28.5 & 28.7 & 29.0 & 29.3 \\
\hline Cote d'Ivoire & 29.9 & 30.1 & 30.9 & 32.3 & 31.1 & 29.4 & 32.5 & 30.9 & 30.8 & 30.5 & 31.7 & 32.3 & 30.8 & 32.0 & 34.0 & 32.1 & 45.1 & 48.6 & 50.4 & 49.6 & 49.7 & 49.3 & 49.5 \\
\hline Croatia & & & & & & & & & & & & & & & & 36.0 & 31.9 & 30.5 & 30.7 & 30.2 & 29.5 & 29.5 & 29.7 \\
\hline Cyprus & & 37.3 & 37.2 & 36.9 & 35.4 & 34.5 & 31.6 & 30.7 & 28.4 & 28.9 & 29.8 & 29.7 & 29.7 & 28.5 & 24.6 & 25.0 & 26.6 & 27.0 & 27.3 & 28.5 & 28.0 & 29.1 & 30.1 \\
\hline Czech Republic & & & & & & & & & & 29.8 & 25.7 & 23.5 & 23.0 & 22.7 & 24.2 & 24.1 & 23.9 & 24.3 & 24.0 & 24.2 & 24.0 & 23.8 & 23.2 \\
\hline Denmark & 17.4 & 17.7 & 18.2 & 18.1 & 18.1 & 17.8 & 17.2 & 17.1 & 17.2 & 17.4 & 17.7 & 17.5 & 17.7 & 17.6 & 17.1 & 17.3 & 16.9 & 16.5 & 16.5 & 16.5 & 16.8 & 17.2 & 16.9 \\
\hline Dominican Republic & 29.9 & 30.8 & 30.0 & 30.4 & 32.5 & 32.9 & 31.2 & 30.6 & 31.6 & 30.9 & 29.1 & 29.2 & 28.2 & 31.6 & 34.9 & 34.6 & 34.9 & 37.6 & 42.6 & 43.2 & 45.0 & 43.4 & 42.7 \\
\hline Ecuador & 29.9 & 36.9 & 30.2 & 30.9 & 32.2 & 34.5 & 31.3 & 33.1 & 40.5 & 41.9 & 40.5 & 36.8 & 36.2 & 35.0 & 35.1 & 40.2 & 46.4 & 41.2 & 41.3 & 39.9 & 40.3 & 41.3 & 43.8 \\
\hline Egypt, Arab Republic & 48.7 & 40.9 & 41.2 & 36.7 & 40.1 & 39.7 & 35.6 & 37.2 & 37.6 & 36.2 & 33.1 & 32.3 & 31.6 & 30.3 & 30.3 & 29.5 & 29.1 & 28.8 & 28.1 & 28.2 & 29.0 & 28.8 & 30.4 \\
\hline El Salvador & & & & & & & & & & & & & & & 30.0 & 30.2 & 30.9 & 28.3 & 30.5 & 30.9 & 29.6 & 31.3 & 33.7 \\
\hline Estonia & & & & & & & & & & & & & & & & 35.7 & 26.5 & 27.5 & 28.3 & 28.6 & 28.6 & 28.5 & 28.7 \\
\hline Ethiopia & & 46.2 & 45.0 & 46.1 & 47.6 & 47.6 & 49.6 & 57.7 & 62.9 & 46.4 & 41.0 & 33.7 & 29.9 & 31.6 & 31.1 & 31.0 & 29.8 & 28.7 & 28.7 & 32.0 & 30.8 & 30.7 & 30.6 \\
\hline France & 20.7 & 20.7 & 20.6 & 20.6 & 20.3 & 20.4 & 20.4 & 20.4 & 18.4 & 18.4 & 18.4 & 13.6 & 14.6 & 16.4 & 16.3 & 16.5 & 16.5 & 18.1 & 19.6 & 19.8 & 18.9 & 18.9 & 19.0 \\
\hline Gabon & 47.3 & 44.5 & 40.6 & 36.9 & 33.7 & 32.4 & 31.8 & 33.0 & 28.2 & 25.8 & 28.1 & 26.4 & 25.5 & 26.7 & 32.6 & 29.4 & 27.8 & 29.4 & 28.9 & 28.3 & 30.8 & 32.0 & 32.3 \\
\hline Gambia, The & & & 37.8 & 39.5 & 40.0 & 41.1 & 41.1 & 41.5 & 36.5 & 35.3 & 29.0 & 26.9 & 26.8 & 26.2 & 25.3 & 25.4 & 25.9 & 26.7 & 26.7 & 27.1 & 31.6 & 32.1 & 31.9 \\
\hline Germany & & & & & & & & 15.5 & 16.5 & 17.7 & 16.4 & 11.2 & 11.1 & 11.1 & 11.1 & 11.3 & 12.0 & 13.0 & 13.0 & 13.0 & 12.9 & 12.9 & 13.0 \\
\hline Ghana & 52.7 & 45.0 & 46.6 & 48.0 & 45.6 & 32.4 & 28.6 & 28.0 & 25.7 & 28.4 & 28.8 & 31.1 & 30.7 & 31.5 & 33.5 & 34.7 & 39.0 & 39.9 & 39.0 & 42.1 & 42.9 & 41.4 & 37.6 \\
\hline Greece & 29.6 & 29.6 & 30.3 & 30.1 & 29.4 & 28.5 & 28.3 & 20.7 & 19.3 & 18.4 & 17.2 & 15.7 & 15.7 & 17.2 & 19.7 & 22.7 & 23.2 & 22.9 & 22.7 & 22.4 & 21.5 & 18.5 & 18.5 \\
\hline
\end{tabular}




\begin{tabular}{|c|c|c|c|c|c|c|c|c|c|c|c|c|c|c|c|c|c|c|c|c|c|c|c|}
\hline Guatemala & & & & & & & 53.0 & 52.9 & 47.1 & 43.7 & 35.2 & 32.0 & 32.9 & 30.7 & 31.7 & 32.4 & 32.3 & 32.1 & 34.9 & 34.9 & 34.9 & 30.7 & 32.4 \\
\hline Guinea & & & & & & 36.0 & 35.7 & 35.7 & 35.8 & 34.2 & 34.2 & 34.5 & 34.3 & 31.8 & 28.6 & 29.2 & 26.2 & 26.1 & 28.1 & 29.1 & 28.6 & 29.1 & 30.5 \\
\hline Guinea-Bissau & & & 44.3 & 46.7 & 45.7 & 42.2 & 45.4 & 47.2 & 46.3 & 43.3 & 41.4 & 42.6 & 43.0 & 43.4 & 42.8 & 43.6 & 47.2 & 45.6 & 45.8 & 45.3 & 39.1 & 40.4 & 36.7 \\
\hline Guyana & 84.4 & 84.0 & 83.7 & 76.9 & 80.2 & 80.3 & 76.8 & 78.5 & 79.3 & 59.1 & 49.2 & 42.5 & 43.0 & 38.5 & 35.7 & 34.7 & 36.2 & 33.8 & 36.7 & 43.5 & 40.8 & 39.9 & 39.5 \\
\hline Honduras & & & & & & & & & & & & & & & & & & & & 40.2 & 40.8 & 40.7 & 41.3 \\
\hline Hungary & 47.7 & 44.9 & 48.3 & 48.0 & 48.5 & 46.8 & 46.8 & 44.8 & 43.7 & 43.9 & 42.6 & 38.0 & 27.6 & 25.2 & 24.2 & 24.4 & 27.7 & 28.2 & 27.6 & 27.4 & 29.0 & 29.8 & 29.7 \\
\hline Iceland & 16.0 & 15.9 & 15.4 & 15.3 & 16.2 & 16.4 & 16.1 & 15.7 & 15.8 & 15.6 & 15.4 & 15.5 & 15.8 & 15.4 & 15.1 & 15.7 & 15.7 & 15.1 & 15.1 & 15.2 & 15.5 & 16.2 & 16.5 \\
\hline India & 27.1 & 28.7 & 29.2 & 29.2 & 29.2 & 29.0 & 33.5 & 32.5 & 25.1 & 22.3 & 21.6 & 21.8 & 21.7 & 21.5 & 21.1 & 21.1 & 21.1 & 20.5 & 21.0 & 21.3 & 21.7 & 22.3 & 22.6 \\
\hline Indonesia & 57.2 & 55.2 & 51.9 & 52.6 & 51.8 & 52.1 & 54.9 & 50.4 & 35.3 & 29.3 & 30.5 & 28.2 & 27.3 & 30.4 & 37.4 & 35.1 & 31.6 & 32.5 & 34.1 & 34.3 & 31.5 & 35.1 & 36.3 \\
\hline Iran, Islamic Republic & 38.2 & 36.8 & 37.1 & 36.8 & 42.1 & 41.4 & 39.8 & 34.0 & 27.5 & 21.0 & 18.7 & 19.5 & 20.1 & 22.6 & 23.5 & 23.4 & 21.0 & 22.2 & 22.5 & 22.9 & 23.0 & 24.3 & 24.1 \\
\hline Italy & 22.6 & 22.3 & 23.3 & 23.2 & 22.8 & 23.1 & 23.3 & 22.4 & 22.2 & 22.7 & 22.1 & 17.3 & 16.1 & 17.1 & 17.6 & 17.7 & 17.3 & 18.1 & 22.3 & 24.9 & 23.6 & 22.4 & 22.9 \\
\hline Jamaica & 52.0 & 50.7 & 49.0 & 47.5 & 46.6 & 46.1 & 45.8 & 46.7 & 47.0 & 40.6 & 37.5 & 36.8 & 36.3 & 35.0 & 35.5 & 39.6 & 40.4 & 39.8 & 45.3 & 48.9 & 46.1 & 40.8 & 43.2 \\
\hline Japan & 13.1 & 13.1 & 13.0 & 13.3 & 13.4 & 13.5 & 13.7 & 13.8 & 12.3 & 11.4 & 15.5 & 15.6 & 15.8 & 16.5 & 15.6 & 15.5 & 17.3 & 17.5 & 17.2 & 17.1 & 17.3 & 17.6 & 17.7 \\
\hline Jordan & 35.8 & 36.3 & 34.7 & 34.5 & 35.8 & 37.6 & 40.1 & 36.7 & 35.7 & 33.8 & 28.9 & 27.7 & 29.4 & 30.3 & 31.9 & 31.7 & 32.4 & 32.2 & 31.3 & 31.8 & 34.1 & 36.7 & 38.3 \\
\hline Kenya & 30.2 & 29.2 & 28.1 & 29.1 & 29.6 & 29.5 & 33.6 & 31.7 & 32.7 & 31.0 & 28.6 & 29.8 & 26.8 & 28.5 & 35.8 & 37.3 & 38.2 & 38.7 & 40.1 & 37.4 & 38.3 & 37.9 & 36.8 \\
\hline Korea, Republic & 21.2 & 22.0 & 25.0 & 25.1 & 25.5 & 25.3 & 25.3 & 21.9 & 15.2 & 15.1 & 15.2 & 15.2 & 15.3 & 17.9 & 18.9 & 18.6 & 19.2 & 19.1 & 19.0 & 17.9 & 16.8 & 17.0 & 19.7 \\
\hline Latvia & & & & & & & & & & & & & & & & 29.1 & 26.4 & 24.7 & 24.1 & 24.4 & 24.3 & 25.4 & 25.9 \\
\hline Lebanon & & & & & & & & & & 31.7 & 31.6 & 32.5 & 34.3 & 30.6 & 28.2 & 28.6 & 26.9 & 26.8 & 29.4 & 29.8 & 30.3 & 29.1 & 29.3 \\
\hline Liberia & 59.2 & 57.6 & 55.4 & 54.7 & 56.8 & & & & & & & & & & & & & 52.1 & 52.4 & 45.9 & 47.6 & 49.2 & 49.1 \\
\hline Lithuania & & & & & & & & & & & & & & & & 36.7 & 29.0 & 27.5 & 29.1 & 28.8 & 28.9 & 29.3 & 29.8 \\
\hline Luxembourg & & 19.3 & 18.6 & 18.8 & 18.5 & 18.2 & 18.4 & 18.0 & 18.5 & 19.0 & 19.2 & 19.2 & 19.5 & 19.0 & 19.0 & 15.3 & 15.7 & 15.5 & 15.3 & 15.2 & 15.2 & 15.5 & 15.1 \\
\hline Madagascar & & & & & 27.2 & 24.9 & 27.1 & 27.2 & 37.0 & 36.3 & 33.8 & 34.9 & 33.3 & 33.1 & 33.6 & 34.9 & 35.3 & 33.6 & 34.0 & 35.1 & 36.8 & 42.6 & 36.5 \\
\hline Malawi & 45.0 & 45.7 & 45.0 & 45.3 & 46.9 & 46.2 & 44.4 & 39.9 & 42.4 & 40.3 & 53.6 & 44.6 & 36.1 & 34.7 & 30.8 & 30.6 & 30.7 & 31.4 & 29.6 & 30.2 & 30.6 & 30.8 & 30.4 \\
\hline Malaysia & 28.8 & 28.9 & 28.2 & 25.1 & 31.1 & 34.0 & 35.4 & 36.5 & 36.6 & 33.3 & 31.0 & 30.6 & 26.8 & 27.1 & 25.1 & 26.9 & 27.9 & 31.5 & 31.5 & 30.5 & 31.1 & 29.8 & 30.7 \\
\hline Mali & 47.5 & 48.9 & 49.0 & 49.3 & 49.5 & 49.6 & 49.7 & 49.9 & 49.3 & 45.6 & 47.2 & 46.5 & 46.2 & 45.7 & 46.1 & 45.7 & 45.8 & 46.9 & 46.0 & 46.3 & 47.5 & 48.5 & 48.2 \\
\hline Malta & & & 44.1 & 43.1 & 44.1 & 43.9 & 40.4 & 37.2 & 31.5 & 32.1 & 29.3 & 30.2 & 24.6 & 26.3 & 26.7 & 27.1 & 27.6 & 29.8 & 31.2 & 30.7 & 31.8 & 31.9 & 32.4 \\
\hline Mexico & 32.8 & 37.9 & 41.8 & 43.8 & 36.6 & 32.5 & 31.2 & 30.7 & 30.4 & 29.7 & 29.0 & 30.7 & 30.8 & 28.7 & 27.6 & 29.7 & 30.0 & 34.2 & 33.7 & 34.3 & 30.6 & 31.1 & 31.2 \\
\hline Moldova & & & & & & & & & & & & & & & & 29.2 & 28.5 & 25.3 & 25.6 & 27.4 & 31.1 & 35.8 & 36.8 \\
\hline Mongolia & & & & & & & & & 42.3 & 52.7 & 37.0 & 33.1 & 33.3 & 34.0 & 29.4 & 30.2 & 35.0 & 35.9 & 34.4 & 33.4 & 31.6 & 30.1 & 28.0 \\
\hline Morocco & 39.5 & 36.4 & 36.3 & 40.1 & 41.6 & 42.1 & 42.9 & 42.6 & 37.8 & 36.1 & 34.0 & 31.8 & 31.8 & 32.0 & 31.8 & 32.5 & 31.2 & 29.9 & 28.8 & 30.2 & 30.9 & 32.0 & 32.8 \\
\hline Namibia & & & & & & & 46.9 & 48.0 & 36.6 & 33.2 & 31.4 & 30.4 & 29.4 & 33.6 & 36.0 & 38.1 & 36.8 & 36.4 & 35.7 & 33.6 & 33.0 & 35.3 & 37.9 \\
\hline Netherlands & 19.8 & 19.6 & 19.6 & 20.1 & 20.2 & 19.6 & 19.6 & 20.3 & 20.1 & 20.3 & 19.9 & 14.4 & 14.6 & 14.5 & 14.4 & 14.6 & 14.5 & 14.7 & 14.6 & 14.3 & 14.3 & 14.6 & 14.8 \\
\hline New Zealand & 16.8 & 17.6 & 17.6 & 18.6 & 17.9 & 19.0 & 18.4 & 17.5 & 16.7 & 16.5 & 17.0 & 17.0 & 17.7 & 16.6 & 16.8 & 16.1 & 16.1 & 16.5 & 16.4 & 16.7 & 16.7 & 17.5 & 18.7 \\
\hline Nicaragua & 78.7 & 77.6 & 80.1 & 79.0 & 73.5 & 76.2 & 77.6 & 69.6 & 47.4 & 42.3 & 35.2 & 33.0 & 33.1 & 34.1 & 34.9 & 34.4 & 34.3 & 33.2 & 33.6 & 35.1 & 35.8 & 36.7 & 37.2 \\
\hline Nigeria & 51.6 & 39.7 & 42.5 & 40.0 & 45.5 & 42.5 & 41.8 & 32.5 & 29.5 & 30.2 & 29.1 & 34.3 & 32.4 & 36.6 & 45.9 & 46.9 & 36.2 & 40.3 & 40.8 & 42.5 & 42.1 & 41.8 & 40.5 \\
\hline Norway & 17.7 & 19.1 & 19.7 & 19.3 & 18.9 & 18.4 & 18.5 & 18.5 & 18.2 & 18.0 & 17.7 & 17.2 & 17.2 & 17.5 & 17.7 & 17.2 & 16.0 & 15.8 & 16.0 & 15.6 & 15.9 & 16.3 & 16.4 \\
\hline Pakistan & 38.9 & 34.1 & 35.0 & 34.9 & 35.1 & 35.4 & 40.2 & 40.0 & 38.9 & 34.8 & 31.4 & 31.5 & 30.1 & 28.4 & 30.8 & 30.9 & 28.4 & 28.3 & 28.5 & 28.9 & 28.8 & 28.3 & 28.1 \\
\hline Papua New Guinea & 28.9 & 27.5 & 27.7 & 28.1 & 28.2 & 31.9 & 32.5 & 31.0 & 31.2 & 32.5 & 33.4 & 34.0 & 34.7 & 36.9 & 37.4 & 38.6 & 40.3 & 44.6 & 41.7 & 37.2 & 36.4 & 33.5 & 31.7 \\
\hline Paraguay & 46.4 & 47.2 & 47.6 & 47.5 & 47.3 & 47.9 & 48.9 & 43.7 & 26.9 & 25.6 & 26.3 & 27.0 & 26.2 & 28.1 & 31.7 & 33.5 & 33.9 & 34.0 & 37.8 & 39.2 & 39.0 & 39.6 & 39.8 \\
\hline Peru & 50.9 & 54.8 & 49.0 & 46.9 & 67.7 & 66.4 & 68.7 & 60.9 & 47.1 & 40.1 & 37.4 & 37.2 & 37.6 & 34.9 & 31.7 & 30.5 & 30.1 & 30.2 & 29.7 & 30.5 & 30.8 & 31.0 & 32.3 \\
\hline Philippines & 45.8 & 47.8 & 48.7 & 48.3 & 55.2 & 57.2 & 58.1 & 59.1 & 47.6 & 37.5 & 36.0 & 36.1 & 32.0 & 29.4 & 26.6 & 25.5 & 27.4 & 31.4 & 30.3 & 30.5 & 30.4 & 30.0 & 29.9 \\
\hline Poland & & 56.6 & 54.6 & 53.5 & 54.6 & 63.2 & 63.5 & 44.4 & 39.3 & 40.8 & 38.1 & 37.1 & 37.4 & 36.6 & 36.9 & 35.0 & 35.2 & 26.7 & 27.2 & 27.1 & 26.3 & 26.4 & 26.3 \\
\hline Portugal & 23.7 & 25.1 & 25.4 & 23.5 & 24.0 & 24.4 & 23.9 & 21.1 & 21.6 & 21.0 & 20.7 & 19.3 & 19.3 & 18.0 & 18.5 & 18.6 & 18.7 & 18.6 & 18.7 & 18.7 & 18.4 & 18.6 & 18.8 \\
\hline Russian Federation & & & & & & & & & & & 48.9 & 45.4 & 35.3 & 34.9 & 40.1 & 39.3 & 37.9 & 39.7 & 36.1 & 34.0 & 33.9 & 36.7 & 36.6 \\
\hline Senegal & & & & & & & & & & & & & 31.7 & 34.0 & 37.5 & 38.1 & 38.6 & 38.8 & 40.2 & 36.2 & 36.6 & 33.1 & 33.3 \\
\hline
\end{tabular}




\begin{tabular}{|c|c|c|c|c|c|c|c|c|c|c|c|c|c|c|c|c|c|c|c|c|c|c|c|}
\hline Sierra Leone & & 26.0 & 25.5 & 32.6 & 26.3 & 28.5 & 29.9 & 38.1 & 49.2 & 50.4 & 50.8 & 48.0 & 40.7 & 41.5 & 43.3 & 41.8 & 43.0 & 45.0 & 44.0 & 44.9 & 44.0 & 45.5 & 45.3 \\
\hline Singapore & 25.2 & 22.9 & 20.5 & 21.0 & 21.7 & 23.0 & 22.3 & 22.8 & 23.4 & 23.4 & 22.3 & 21.1 & 21.2 & 20.3 & 18.4 & 18.9 & 19.1 & 19.0 & 17.5 & 18.9 & 18.8 & 18.9 & 18.9 \\
\hline Slovak Republic & & & & & & & & & & & & & 36.8 & 36.6 & 36.6 & 36.1 & 37.5 & 37.0 & 39.4 & 27.3 & 27.2 & 25.5 & 25.1 \\
\hline Slovenia & & & & & & & & & & & & & & & & 29.4 & 28.4 & 28.4 & 27.7 & 29.6 & 29.3 & 29.3 & 29.7 \\
\hline South Africa & 31.5 & 36.0 & 36.6 & 36.4 & 37.0 & 39.2 & 41.4 & 42.9 & 35.4 & 33.9 & 30.3 & 31.5 & 33.1 & 35.4 & 40.8 & 43.9 & 43.7 & 44.4 & 45.2 & 46.6 & 42.6 & 44.1 & 45.5 \\
\hline Spain & 21.6 & 22.0 & 22.5 & 22.8 & 22.7 & 23.3 & 22.9 & 22.7 & 19.1 & 18.7 & 18.7 & 15.1 & 14.0 & 15.9 & 19.0 & 19.2 & 17.9 & 16.6 & 15.0 & 14.3 & 15.5 & 16.0 & 16.1 \\
\hline Sri Lanka & 46.5 & 44.9 & 44.3 & 44.6 & 44.9 & 56.2 & 57.1 & 55.7 & 50.0 & 37.4 & 34.4 & 32.8 & 31.8 & 30.8 & 32.3 & 32.5 & 32.1 & 32.7 & 32.0 & 31.1 & 31.7 & 32.3 & 33.2 \\
\hline Sweden & 17.2 & 17.5 & 17.1 & 17.9 & 18.1 & 18.1 & 18.6 & 17.9 & 17.5 & 16.4 & 15.8 & 17.0 & 17.6 & 17.6 & 14.0 & 14.3 & 13.7 & 14.6 & 13.5 & 13.7 & 13.8 & 14.0 & 14.1 \\
\hline Switzerland & 13.5 & 13.5 & 13.6 & 13.6 & 13.8 & 13.7 & 10.7 & 10.7 & 10.6 & 10.4 & 10.4 & 10.5 & 10.6 & 10.6 & 10.9 & 10.8 & 11.2 & 11.2 & 12.5 & 12.5 & 12.6 & 12.7 & 18.2 \\
\hline Syrian Arab Republic & & & 42.1 & 45.3 & 43.3 & 44.2 & 44.4 & 41.4 & 36.4 & 32.0 & 32.1 & 31.3 & 27.9 & 29.9 & 32.7 & 33.8 & 29.8 & 30.3 & 29.9 & 31.3 & 33.0 & 31.7 & 31.0 \\
\hline Thailand & 29.5 & 27.5 & 27.4 & 27.5 & 25.2 & 24.9 & 26.0 & 26.5 & 24.0 & 22.9 & 23.4 & 23.6 & 24.2 & 26.1 & 26.9 & 26.0 & 26.3 & 26.5 & 26.5 & 32.8 & 34.8 & 36.1 & 35.7 \\
\hline Togo & 48.6 & 49.3 & 48.1 & 47.4 & 46.9 & 46.4 & 46.1 & 45.7 & 45.4 & 44.8 & 45.2 & 41.1 & 40.0 & 43.2 & 49.1 & 48.6 & 48.4 & 48.2 & 47.8 & 47.1 & 47.0 & 47.0 & 47.4 \\
\hline Trinidad and Tobago & & & & & & & & & & 36.3 & 34.8 & 35.6 & 35.4 & 33.6 & 31.5 & 31.3 & 31.2 & 31.3 & 31.1 & 35.3 & 38.8 & 41.5 & 42.5 \\
\hline Tunisia & 45.4 & 44.2 & 44.5 & 43.4 & 42.4 & 43.5 & 40.5 & 41.0 & 33.9 & 34.2 & 34.0 & 32.6 & 30.8 & 31.1 & 31.8 & 31.7 & 31.9 & 32.1 & 32.0 & 31.3 & 31.5 & 31.8 & 31.8 \\
\hline Turkey & 31.6 & 31.8 & 31.6 & 32.2 & 33.0 & 33.6 & 36.7 & 37.4 & 27.3 & 27.9 & 31.2 & 28.2 & 29.0 & 34.8 & 38.1 & 39.9 & 38.3 & 39.7 & 39.5 & 38.8 & 35.7 & 35.8 & 37.1 \\
\hline Uganda & 56.8 & 61.4 & 59.1 & 61.0 & 61.0 & 54.8 & 53.2 & 49.8 & 41.9 & 31.7 & 30.1 & 30.2 & 30.4 & 28.2 & 25.3 & 26.8 & 26.2 & 26.0 & 26.7 & 27.3 & 27.4 & 27.7 & 28.1 \\
\hline Ukraine & & & & & & & & & & & & & & & & 34.4 & 35.6 & 32.9 & 33.1 & 33.8 & 33.7 & 37.2 & 37.6 \\
\hline United Arab Emirates & & 20.3 & 20.0 & 20.5 & 20.4 & 20.4 & 20.6 & 20.3 & 17.8 & 17.7 & 18.1 & 18.6 & 18.9 & 16.9 & 14.7 & 15.8 & 16.2 & 14.5 & 15.0 & 15.1 & 15.3 & 15.8 & \\
\hline United Kingdom & 18.1 & 20.0 & 21.4 & 21.2 & 21.3 & 20.5 & 19.6 & 19.6 & 17.5 & 16.9 & 17.2 & 17.4 & 17.4 & 17.5 & 16.2 & 16.2 & 16.4 & 16.2 & 15.9 & 15.8 & 16.2 & 16.9 & 17.2 \\
\hline United States & 13.0 & 13.1 & 12.9 & 13.3 & 13.2 & 13.3 & 13.3 & 13.2 & 13.0 & 13.1 & 13.2 & 13.3 & 13.4 & 13.5 & 13.6 & 13.7 & 14.0 & 11.7 & 11.7 & 12.6 & 12.7 & 13.1 & 13.3 \\
\hline Uruguay & 44.4 & 47.7 & 49.4 & 47.6 & 46.7 & 47.4 & 44.9 & 44.9 & 43.6 & 44.7 & 43.8 & 41.9 & 38.3 & 33.8 & 36.3 & 34.5 & 33.8 & 34.4 & 36.9 & 38.0 & 37.3 & 37.2 & 37.8 \\
\hline Venezuela, RB & 36.2 & 36.4 & 32.4 & 29.9 & 31.4 & 33.1 & 34.1 & 33.9 & 30.0 & 30.3 & 31.9 & 31.0 & 33.7 & 36.1 & 34.9 & 34.8 & 34.2 & 34.0 & 39.6 & 46.5 & 39.1 & 39.2 & 39.9 \\
\hline Vietnam & & & & & & & & & & & 35.4 & 30.8 & 30.6 & 28.6 & 28.4 & 28.1 & 27.9 & 30.3 & 30.5 & 31.5 & 32.9 & 33.1 & 33.9 \\
\hline Yemen, Republic & & & & & & & & 32.9 & 31.0 & 33.4 & 29.8 & 28.8 & 27.6 & 27.9 & 36.3 & 37.4 & 41.1 & 43.0 & 44.0 & 43.9 & & & \\
\hline Zambia & 52.9 & 48.8 & 51.5 & 47.7 & 45.1 & 50.8 & 54.6 & 55.8 & 49.4 & 46.9 & 44.2 & 39.5 & 39.5 & 38.3 & 38.3 & 39.1 & 39.1 & 38.9 & 38.1 & 37.5 & 37.8 & 37.4 & 37.0 \\
\hline Zimbabwe & 48.2 & 37.4 & 38.4 & 39.8 & 41.1 & 42.4 & 42.6 & 41.6 & 36.4 & 34.2 & 30.6 & 33.1 & 32.7 & 36.8 & $\begin{aligned} 31.8 \\
\end{aligned}$ & 31.4 & 36.4 & 45.4 & 56.4 & 65.2 & 59.9 & 58.1 & \\
\hline
\end{tabular}




\section{References}

Ahumada, Hildegart, Facundo Alvaredo and Alfredo Canavese. 2007. The Monetary Method and the Size of the Shadow Economy: A Critical Assessment. Review of Income Wealth 53 (2): 363-371.

Ahumada, Hildegart, Facundo Alvaredo and Alfredo Canavese. 2008. The Monetary Method to Measure the Shadow Economy: The Forgotten Problem of the Initial Conditions. Economics Letters 101 (1): 97-99.

Allingham, Michael G. and Agnar Sandmo (1972). Income Tax Evasion: A Theoretical Analysis. Journa/ of Public Economics 1 (3-4): 323-338.

Alm, James, Jorge Martinez-Vazquez and Friedrich Schneider. 2004. Sizing the Problem of the Hard-to-tax. In Taxing the Hard-to-tax: Lessons from Theory and Practice, Jame Alm, Jorge Martinez-Vazquez and Sally Wallace, ed., 11-75. Elsevier B. V. - North Holland Publishers, Amsterdam, The Netherlands.

Arellano, Manuel and Stephen Bond. 1991. Some Tests of Specification for Panel Data: Monte Carlo Evidence and an Application to Employment Equations. Review of Economic Studies 58 (2): 277-297.

Arellano, Manuel and Olympia Bover. 1995. Another Look at the Instrumental Variable Estimation of Errorcomponents Models. Journal of Econometrics 68 (1): 29-51.

Blundell, Richard and Stephen Bond. 1998. Initial Conditions and Moment Restrictions in Dynamic Panel Data Models. Journal of Econometrics 87: 115-143.

Bagachwa, M. S. D. and A. Naho (1995). Estimating the Second Economy in Tanzania. World Development 23 (8): 1387-1399.

Bajada, Chris. 1999. Estimates of the Underground Economy in Australia. Economic Record 75 (4): 369-384.

Bhattacharyya, Dilip K. 1990. An Econometric Method of Estimating the "Hidden Economy," United Kingdom (1960-1984): Estimates and Tests. The Economic Journal 100 (402): 703-717

Bhattacharyya, Dilip K. 1999. On the Economic Rationale of Estimating the Hidden Economy. The Economic Journal 109 (456): F348-F359.

Cagan, Phillip. 1958. The Demand for Currency Relative to Total Money Supply. The Journal of Political Economy 66 (4): 303-329.

Carolina, Mureka G. L. and Lennie Pau. 2007. The Shadow Economy in the Netherlands Antilles. Social and Economic Studies 56(4): 46-81.

Crane, Steven E. and Farrokh Nourzad. 1986. Inflation and Tax Evasion: An Empirical Analysis. The Review of Economics and Statistics 68 (2): 217-223.

Dell'Anno, Roberto. and Friedrich Schneider. 2003. The Shadow Economy of Italy and Other OECD Countries: What Do We Know? Journal of Public Finance and Public Choice/Economia delle Scelte Pubbliche 21 (2-3): 97-120.

Faal, Ebrima. 2003. Currency Demand, the Underground Economy, and Tax Evasion: The Case of Guyana. IMF Working Papers, 03/7. Washington, D.C.

Feige, Edgar L. 1996. Overseas Holdings of U.S. Currency and the Underground Economy. In Exploring the Underground Economy: Studies of Illegal and Unreported Activity, S. Pozo, ed, 5-62. W. E. Upjohn Institute for Employment Research, Kalamazoo, MI.

Feige, Edgar L. 1989. The Underground Economies: Tax Evasion and Information Distortion. Cambridge University Press, Cambridge, New York and Melbourne.

Feige, Edgar L. 1979. How Big is the Irregular Economy? Challenge 22 (1): 5-13.

Feld, Lars P. and Bruno S. Frey. 2000. Trust Breeds Trust: How Taxpayers Are Treated. Economics of Governance 3 (1): 87-99.

Fishburn, Geoffrey . 1981. Tax Evasion and Inflation. Australian Economic Papers 20 (37): 325-332.

Fleming, Matthew H., John Roman, and Graham Farrel. 2000. The Shadow Economy. Journal of International Affairs 53 (2): 64-89.

Frey, Bruno S. 1992. Tertium Datur: Pricing, Regulating, and Intrinsic Motivation. Kyklos 45 (2) : 161-184. 
Giles, David E. A. 1999a. Measuring the hidden economy: Implications for econometric modelling. The Economic Journal, 109 (456): F370-F380.

Giles, David E. A. 1999b. Modelling the hidden economy and the tax-gap in New Zealand. Empirical

Economics 24 (4): 621-640.

Giles, David E. A. and Lindsay M. Tedds. 2002. Taxes and the Canadian Underground Economy. Toronto, Ontario: Canadian Tax Foundation.

Gutmann, Peter M. 1977. The Subterranean Economy. Financial Analysts Journa/ 33: 26-28.

Hansen, Lars. 1982. Large Sample Properties of Generalized Method of Moments Estimators. Econometrica 50 (4) : 1029-1054.

Johnson, Simon, Danile Kaufmann, and Pablo Zoido-Lobaton. 1998. Regulatory Discretion and the Unofficial Economy. The American Economic Review 88 (2): 387-392.

Katircioglu, Salih, Meryem D. Fethi, and Sami Fethi. 2004. Estimating the Underground Economy and Tax Evasion: Cointegration and Causality Evidence in the Case of Cyprus, 1960-2003. International Journal of Economic Development 6 (2) : 120-157.

Klovland, Jan T. 1984. Tax Evasion and the Demand for Currency in Norway and Sweden. Is There a Hidden Relationship? Scandinavian Journal of Economics 86 (4): 423-439.

Matthews, K. G. P. 1982. Demand for Currency and the Black Economy in the UK. Journal of Economic Studies 9 (2): 3-22.

Pierce, Richard G. and Andy J. Snell. 1995. Temporal Aggregation and the Power of Tests for a Unit Root. Journal of Econometrics 65 (3): 333-345.

Roodman, David. 2009. A Note on the Theme of Too Many Instruments. Oxford Bulletin of Economics and Statistics 7 (1) : 135-58.

Schneider, Friedrich. 1997. The Shadow Economies of Western Europe. Journal of the Institute of Economic Affairs 17 (1): 42-48.

Schneider, Friedrich. 2002. The Size and Development of the Shadow Economies of 22 Transition and 21 OECD Countries. Institute for the Study of Labor (IZA) Working Paper, Bonn, Germany.

Schneider, Friedrich. 2005. Shadow Economies Around the World: What Do We Really Know? European Journal of Political Economy 21 (3): 598-642.

Schneider, Friedrich. and Dominik H. Enste. 2000. Shadow Economies: Size, Causes, and Consequences. The Journal of Economic Literature 38 (1): 77-114.

Shima, Isilda. 2005. The Shadow Economy in Norway: Demand for Currency Approach. The IUP Journal of Monetary Economics (IUP Publications) 1 (1): 61-78.

Simanjuntak, Jerry Marmen. 2008. Currency demand modeling in estimating the underground economy: A critique on "excess sensitivity" method and support for VAR framework. Working Papers in Economics and Development Studies (WoPEDS).

Smith, J. D. 1984. Market Motives in the Informal Economy. In: N. Gaertnew and W. Wenig (eds.), The Economics of the Shadow Economy, Springer Publishing Company, Heidelberg, Germany: 166-177.

Tanzi, Vito. 1980. The Underground Economy in the United States: Estimates and Implications. Banca Nazionale del Lavoro Quarterly Review 135: 427-453.

Tanzi, Vito. 1983. The Underground Economy in the United States: Annual Estimates, 1930-80. International Monetary Fund Staff Papers 30 (2): 283-305.

Thomas, Jim. 1992. Informal Economic Activity, Harvester Wheatsheaf, London, UK.

Thomas, Jim. 1999. Quantifying the Black Economy: "Measurement without Theory" Yet Again? The Economic Journal 109 (456): F381-F389.

Torgler, Benno and Friedrich Schneider. 2009. The Impact of Tax Morale and Institutional Quality on the Shadow Economy. Journal of Economic Psychology 30 (2): 228-245.

Williams, Colin C. and Jan Windebank. 1995. Black Market Work in the European Community: Peripheral Work for Peripheral Localities? International Journal of Urban and Regional Research 19 (1): $23-39$. 
Table 1. Sample Countries by Income Group

\begin{tabular}{|c|c|c|}
\hline \multicolumn{3}{|l|}{ Low Income Countries } \\
\hline Bangladesh & India & Papua New Guinea \\
\hline Burkina Faso & Kenya & Senegal \\
\hline Cameroon & Liberia & Sierra Leone \\
\hline Congo, Democratic Republic & Madagascar & Togo \\
\hline Congo, Republic & Malawi & Uganda \\
\hline Cote d'Ivoire & Mali & Vietnam \\
\hline Ethiopia & Moldova & Yemen, Republic \\
\hline Gambia & Mongolia & Zambia \\
\hline Ghana & Nicaragua & Zimbabwe \\
\hline Guinea & Nigeria & \\
\hline Guinea-Bissau & Pakistan & \\
\hline \multicolumn{3}{|c|}{ Lower Middle Income Countries } \\
\hline Albania & Ecuador & Namibia \\
\hline Algeria & Egypt, Arab Republic & Paraguay \\
\hline Armenia & El Salvador & Peru \\
\hline Azerbaijan & Guatemala & Philippines \\
\hline Belarus & Guyana & Sri Lanka \\
\hline Bolivia & Honduras & Syrian Arab Republic \\
\hline Brazil & Indonesia & Thailand \\
\hline Bulgaria & Iran, Islamic Republic & Tunisia \\
\hline China & Jamaica & Ukraine \\
\hline Colombia & Jordan & \\
\hline Dominican Republic & Morocco & \\
\hline \multicolumn{3}{|c|}{ Upper Middle Income Countries } \\
\hline Argentina & Hungary & Slovak Republic \\
\hline Botswana & Latvia & South Africa \\
\hline Chile & Lebanon & Trinidad and Tobago \\
\hline Costa Rica & Lithuania & Turkey \\
\hline Croatia & Malaysia & Uruguay \\
\hline Czech Republic & Mexico & Venezuela, RB \\
\hline Estonia & Poland & \\
\hline Gabon & Russian Federation & \\
\hline \multicolumn{3}{|c|}{ High Income, Non-0ECD Countries } \\
\hline Bahrain & Malta & Slovenia \\
\hline Cyprus & Singapore & United Arab Emirates \\
\hline \multicolumn{3}{|l|}{ OECD Countries } \\
\hline Australia & Iceland & Norway \\
\hline Austria & Italy & Portugal \\
\hline Canada & Japan & Spain \\
\hline Denmark & Korea, Republic & Sweden \\
\hline France & Luxembourg & Switzerland \\
\hline Germany & Netherlands & United Kingdom \\
\hline Greece & New Zealand & United States \\
\hline
\end{tabular}


Table 2. Descriptive Statistics, 1984-2006

\begin{tabular}{|l|c|c|c|c|c|}
\hline Variable & Observations & Mean & $\begin{array}{c}\text { Standard } \\
\text { Deviation }\end{array}$ & Minimum & Maximum \\
\hline Currency Ratio, $C / M 2$ & 2288 & 0.20 & 0.15 & 0.01 & 0.84 \\
\hline Tax Rate, $\tau$ & 2257 & 0.18 & 0.08 & 0.01 & 0.49 \\
\hline Enforcement, $E$ & 2343 & 16.14 & 9.90 & 1 & 35 \\
\hline Inflation Rate, $\pi$ & 2482 & 1.70 & 6.70 & 0.00 & 238.70 \\
\hline Per Capita Income, $Y$ & 2485 & 6375 & 9366 & 56 & 54178 \\
\hline Interest Rate, $R$ & 2226 & 0.91 & 23.22 & 0.0 & 1073 \\
\hline Urbanization, Urban & 2553 & 0.55 & 0.22 & 0.09 & 1.00 \\
\hline
\end{tabular}

Note: $C / M 2, \tau, \pi$, $r$, and Urban are each expressed as a percent (or multiplied by 100) in the estimation.

Table 3. Correlation Matrix

\begin{tabular}{|l|c|c|c|c|c|c|c|}
\hline & $\operatorname{In}(C / M 2)$ & $\operatorname{In}(1+\tau)$ & $\operatorname{In}(1+E)$ & $\ln (1+\pi)$ & $\ln (Y)$ & $R$ & Urban \\
\hline $\operatorname{In}(\mathrm{C} / \mathrm{M} 2)$ & 1 & & & & & & \\
\hline $\operatorname{In}(1+\tau)$ & -0.40 & 1 & & & & & \\
\hline $\operatorname{In}(1+E)$ & -0.58 & 0.45 & 1 & & & & \\
\hline $\operatorname{In}(1+\pi)$ & 0.09 & -0.09 & -0.16 & 1 & & & \\
\hline $\operatorname{In}(Y)$ & -0.64 & 0.46 & 0.74 & -0.09 & 1 & & \\
\hline$R$ & 0.02 & 0.00 & -0.03 & 0.37 & -0.01 & 1 & \\
\hline Urban & -0.42 & 0.27 & 0.51 & 0.01 & 0.80 & 0.01 & 1 \\
\hline
\end{tabular}

Table 4(a). G M M System Estimation Results ${ }^{\mathrm{a}, \mathrm{b}}$

\begin{tabular}{|l|c|}
\hline Independent Variable & $0.91^{* * *}$ \\
\hline $\operatorname{In}(C / M 2)-1$ & $0.01)$ \\
\hline $\ln (1+\tau)$ & $-0.93^{* * *}$ \\
& $0.08)$ \\
\hline $\ln (1+\tau) X O E C D$ & $0.30^{* * *}$ \\
& $0.04)$ \\
\hline $\ln (E)$ & $-0.01^{*}$ \\
& $(0.01)$ \\
\hline $\ln (1+\pi)$ & $0.03^{* * *}$ \\
& $(0.01)$ \\
\hline $\ln (Y)$ & $-0.02^{* * *}$ \\
& $(0.00)$ \\
\hline$R$ & $4.30 \times 10^{-5}$ \\
& $\left(4.13 \times 10^{-5}\right)$ \\
\hline Urban & 0.00 \\
& $0.02)$ \\
\hline Constant & $0.12^{* * *}$ \\
& $0.02)$ \\
\hline Observations & 1884 \\
\hline Number of Countries & 111 \\
\hline Number of Instruments & 109 \\
\hline
\end{tabular}




\begin{tabular}{|l|l|}
\hline A-B test for AR(2), p-value & 0.815 \\
\hline Joint Hansen Test, p-value & 0.271 \\
\hline Difference-in-Hansen Test, p-value & 0.098 \\
\hline
\end{tabular}

${ }^{a}$ The dependent variable is $/ n(C / M 2)$. Standard errors are in parentheses.

${ }^{\mathrm{b}}$ For the equation in difference, the instrument matrix includes the first lags of the tax rate and currency ratio in addition to the other (exogenous) variables of the model which serve as their own instruments. In the level equation, the instrument matrix include the differenced first lags of the tax rate and currency ratio as well as the exogenous variables.

* significant at 10 percent; ** significant at 5 percent; *** significant at 1 percent.

Table 4(b). GMM Difference Estimation Results ${ }^{a, b}$

\begin{tabular}{|l|c|c|c|}
\hline & \multicolumn{3}{|c|}{ Specification } \\
\hline Independent Variable & $(1)$ & $(2)$ & $(3)$ \\
\hline $\operatorname{In}(C / M 2)-1$ & $0.15^{* * *}$ & $0.05^{* * *}$ & $0.10^{* * *}$ \\
& $(0.05)$ & $(0.02)$ & $(0.01)$ \\
\hline $\ln (1+\tau)$ & -0.17 & $0.45^{*}$ & $0.65^{* * *}$ \\
& $(0.42)$ & $(0.26)$ & $(0.12)$ \\
\hline $\ln (1+\tau) X$ OECD & 0.26 & -0.26 & $-0.37^{* * *}$ \\
& $(0.40)$ & $(0.25)$ & $(0.12)$ \\
\hline $\ln (E)$ & $-0.06^{* * *}$ & $-0.04^{* * *}$ & $-0.05^{* * *}$ \\
& $(0.02)$ & $(0.01)$ & $(0.01)$ \\
\hline $\ln (1+\pi)$ & $0.08^{* * *}$ & $0.07^{* * *}$ & $0.06^{* * *}$ \\
& $(0.02)$ & $(0.01)$ & $(0.01)$ \\
\hline $\ln (Y)$ & $-0.17^{* *}$ & $-0.17^{* * *}$ & $-0.13^{* * *}$ \\
& $(0.07)$ & $(0.05)$ & $(0.03)$ \\
\hline$R$ & $1.41 \mathrm{X} 10^{-4}$ & $3.53 \times 10^{-4 * * *}$ & $2.67 \mathrm{X} 10^{-4 * * *}$ \\
& $\left(1.36 \mathrm{X} 10^{-4}\right)$ & $\left(7.22 \mathrm{X} 10^{-5}\right)$ & $\left(3.23 \mathrm{X} 10^{-5}\right)$ \\
\hline Urban & $-0.97^{* *}$ & $-0.90^{* *}$ & $-1.09^{* * *}$ \\
& $(0.43)$ & $(0.35)$ & $(0.24)$ \\
\hline Observations & 1765 & 1765 & 1765 \\
\hline Number of Countries & 111 & 111 & 111 \\
\hline Number of Instruments & 65 & 85 & 104 \\
\hline A-B test for AR(2), p-value & 0.499 & 0.455 & 0.522 \\
\hline Hansen Test, p-value & 0.280 & 0.214 & 0.181 \\
\hline
\end{tabular}

${ }^{a}$ The dependent variable is $\ln (C / M 2)$. Standard errors are in parentheses.

${ }^{b}$ Each specification differs in its set of instruments. The instrument matrix in each specification includes the lagged tax rate and the exogenous variables in the model. In addition to these, specifications (1), (2), and (3) include, respectively, the first lag, the first two lags, and the first three lags of the dependent variable in the instrument matrix.

* significant at 10 percent; $* *$ significant at 5 percent; *** significant at 1 percent 
Table 5. Shadow Economy Estimates (as Percent of GDP): Summary Statistics by Income Group, 1984-2006

\begin{tabular}{|l|c|c|c|c|c|}
\hline Income Group & Observations & Mean & $\begin{array}{c}\text { Standard } \\
\text { Deviation }\end{array}$ & Minimum & Maximum \\
\hline Low Income & 621 & 38.2 & 10.3 & 20.5 & 85.8 \\
\hline Lower Middle Income & 572 & 37.2 & 10.3 & 17.5 & 84.5 \\
\hline Upper Middle Income & 395 & 33.4 & 7.2 & 21.3 & 68.2 \\
\hline High Income, Non-OECD & 118 & 24.3 & 7.1 & 14.1 & 44.1 \\
\hline OECD & 475 & 16.9 & 3.6 & 10.4 & 30.3 \\
\hline All Countries (Unweighted) & 2181 & 31.7 & 12.0 & 10.4 & 85.8 \\
\hline
\end{tabular}

Table 6. Shadow Economy Estimates (as Percent of GDP): Comparison of Schneider (2005) and Current Estimates (Average of 1991, 1995, 2000) ${ }^{\mathrm{a}}$

\begin{tabular}{|l|c|c|c|c|c|}
\hline Period & Observations & Mean & $\begin{array}{c}\text { Standard } \\
\text { Deviation }\end{array}$ & Minimum & Maximum \\
\hline Current Estimates & 88 & 30.8 & 9.7 & 11.4 & 52.3 \\
\hline Schneider Estimates & 88 & 29.4 & 12.6 & 8.4 & 61.0 \\
\hline
\end{tabular}

${ }^{\mathrm{a}}$ To be comparable, our Current Estimates are restricted to the period for which Schneider (2005) reports estimates, and the countries selected are those that are included in both studies.

Figure 1. Shadow Economy (as Percent of GDP): Summary Statistics, 1984-2006

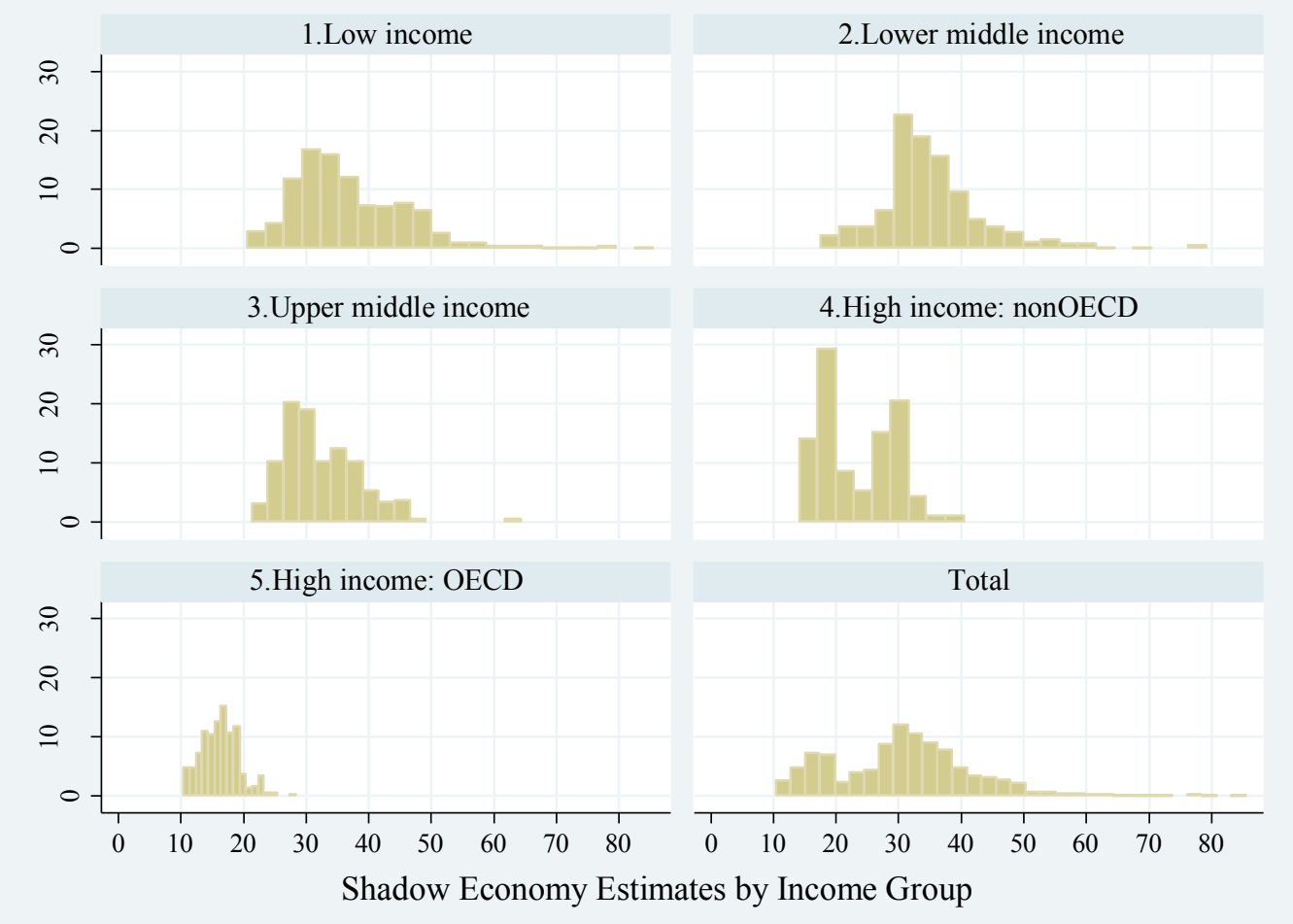


Figure 2. Evolution of Shadow Economy (as Percent of GDP) by Income Group

\section{Panel (a): Low Income}

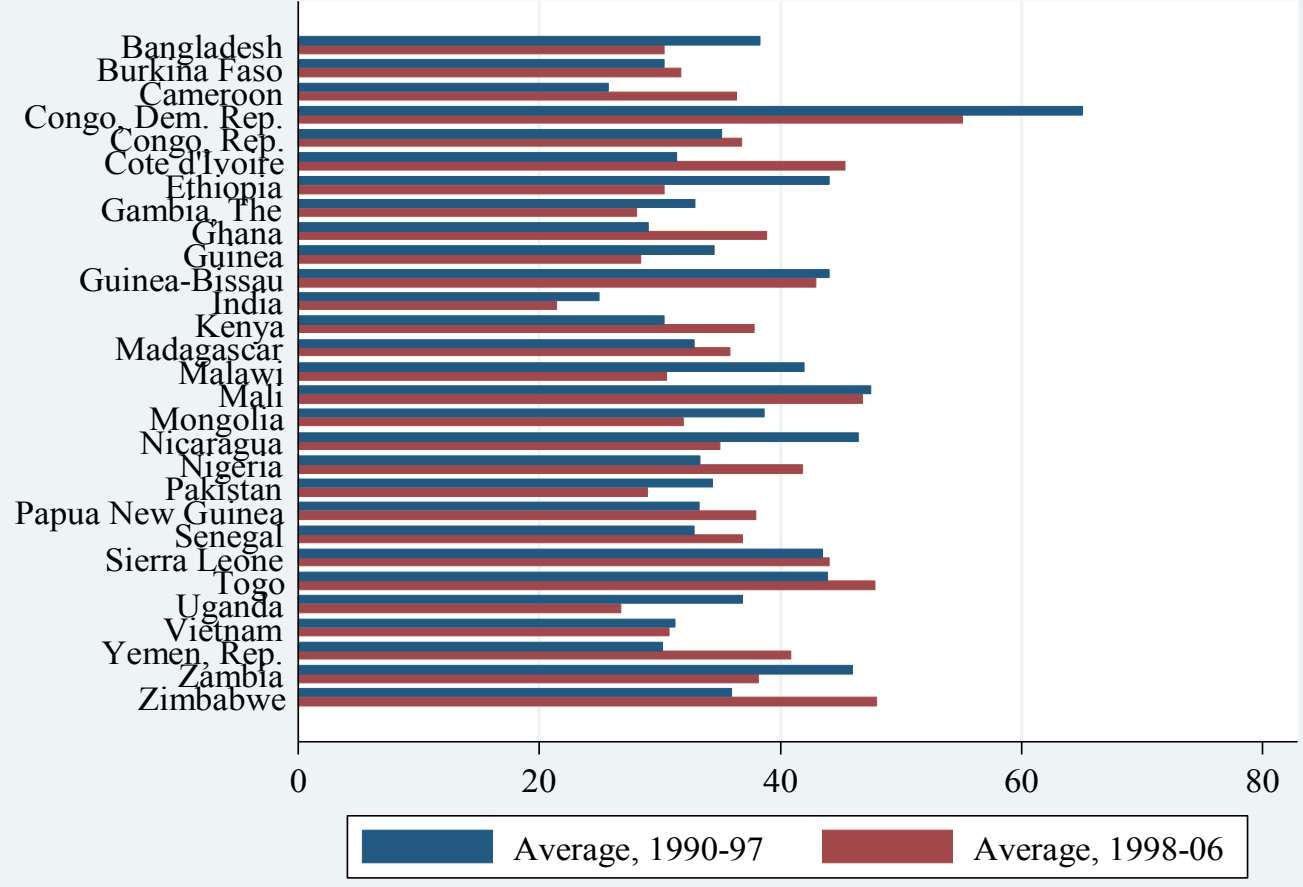

Panel (b): Lower Middle Income

Albania

Algeria

Bolivia

Brazil

Bulgaria

China

Colombia

Ecuador

Egypt, Arab Rep.

Guatemala

Guyana

Indonesia

Iran, Islamic Rep.

Jamaica

Jordan

Morocco

Namibia

Paraguay

Philippines

Sri Lanka

Syrian Arab Republic

Thailand

Tunisia

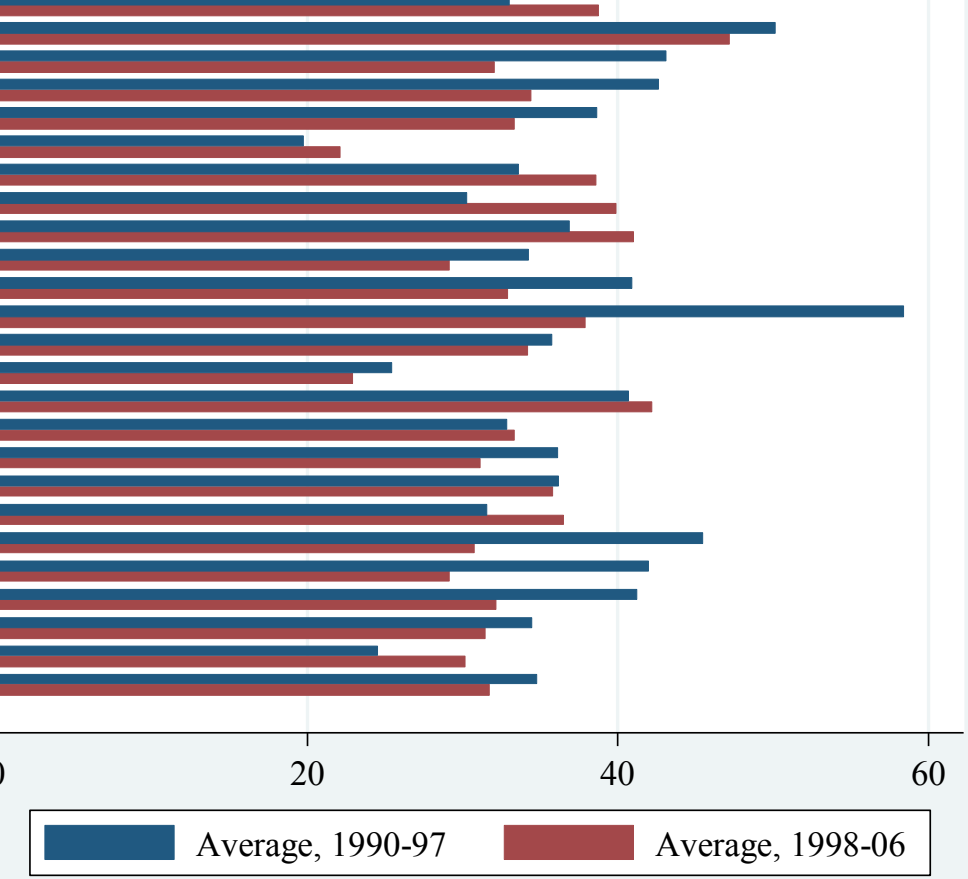


Panel (c): Upper Middle Income

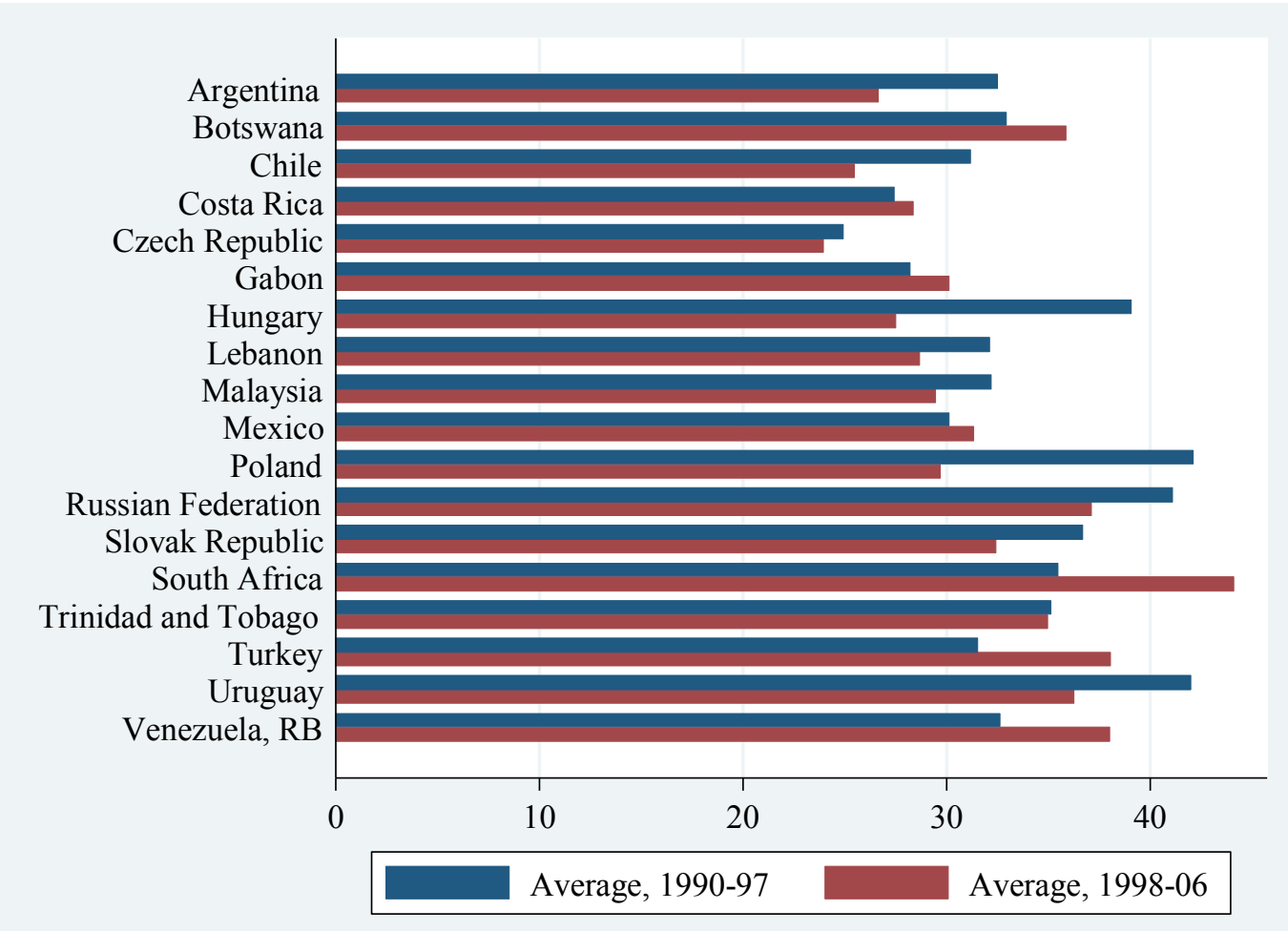

Panel (d): High Income, Non-OECD

United Arab Emirates

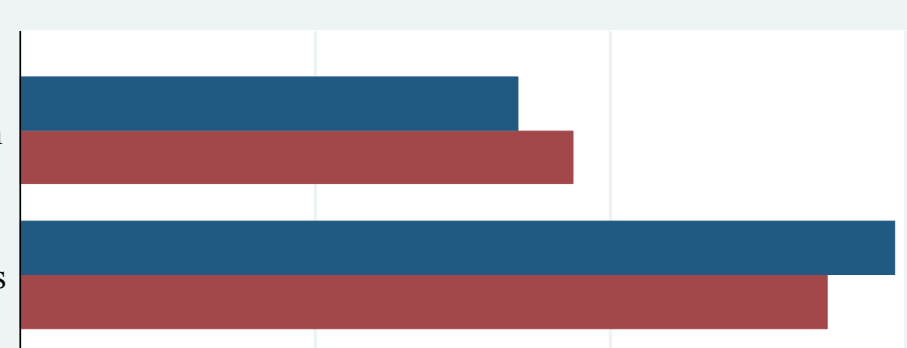

Malta

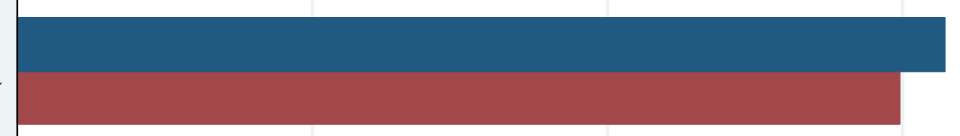

Singapore
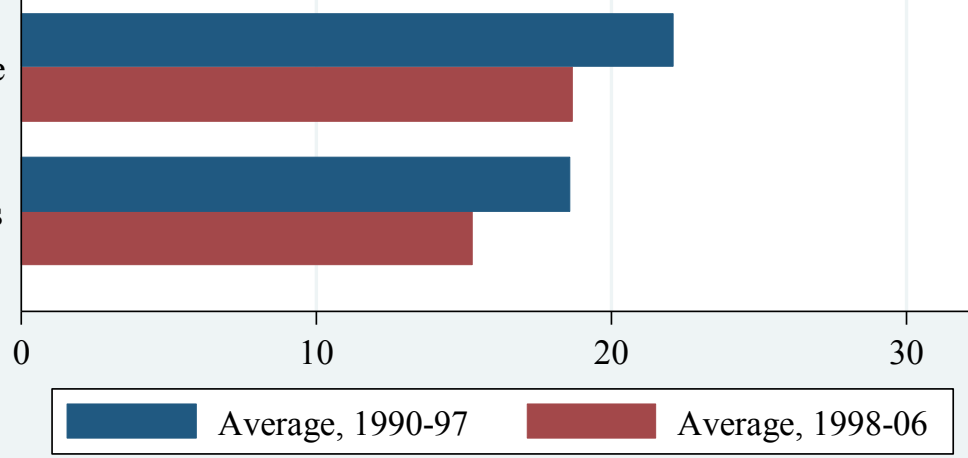


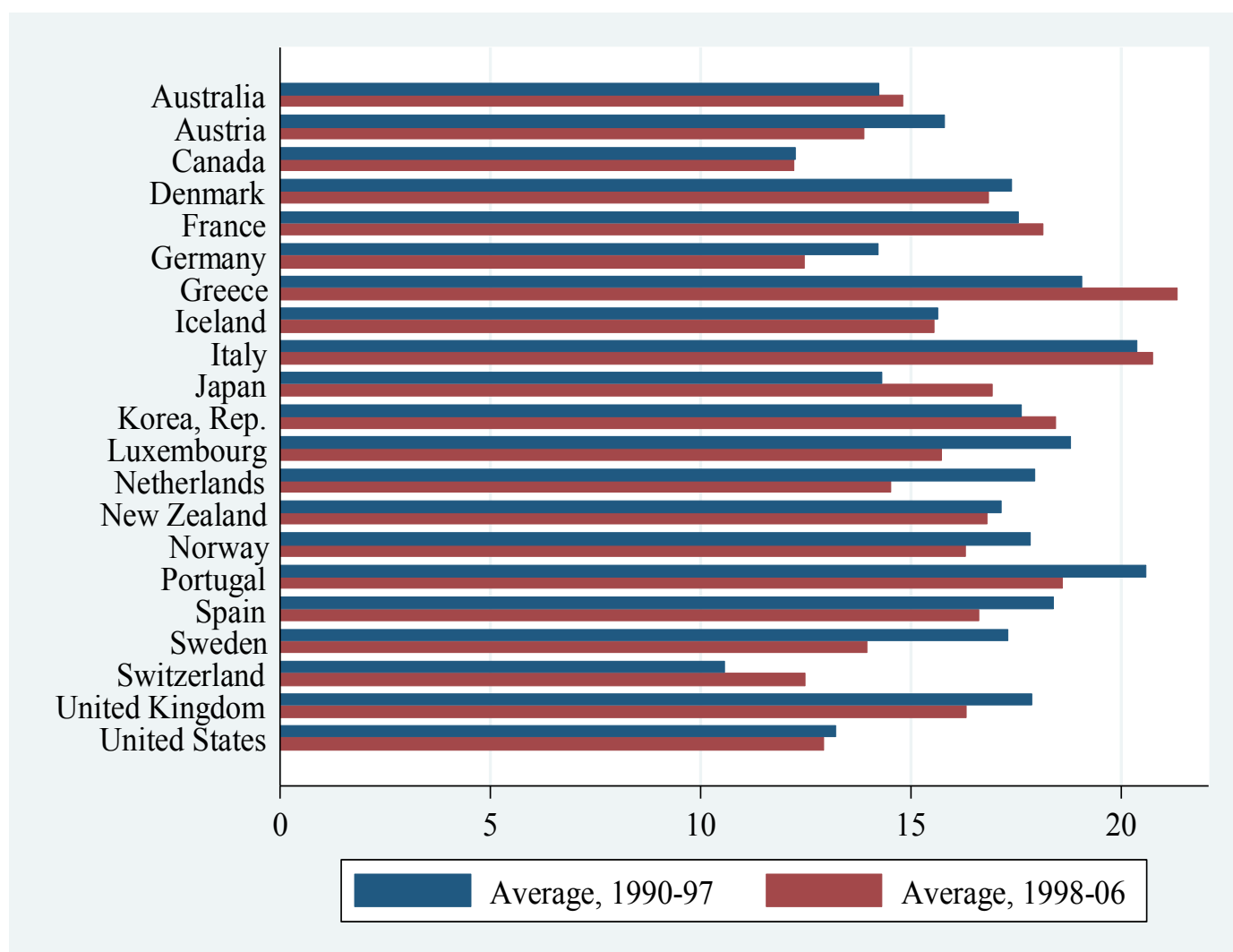


Figure 3. Shadow Economy Estimates (as Percent of GDP): Schneider (2005) and Current Estimates

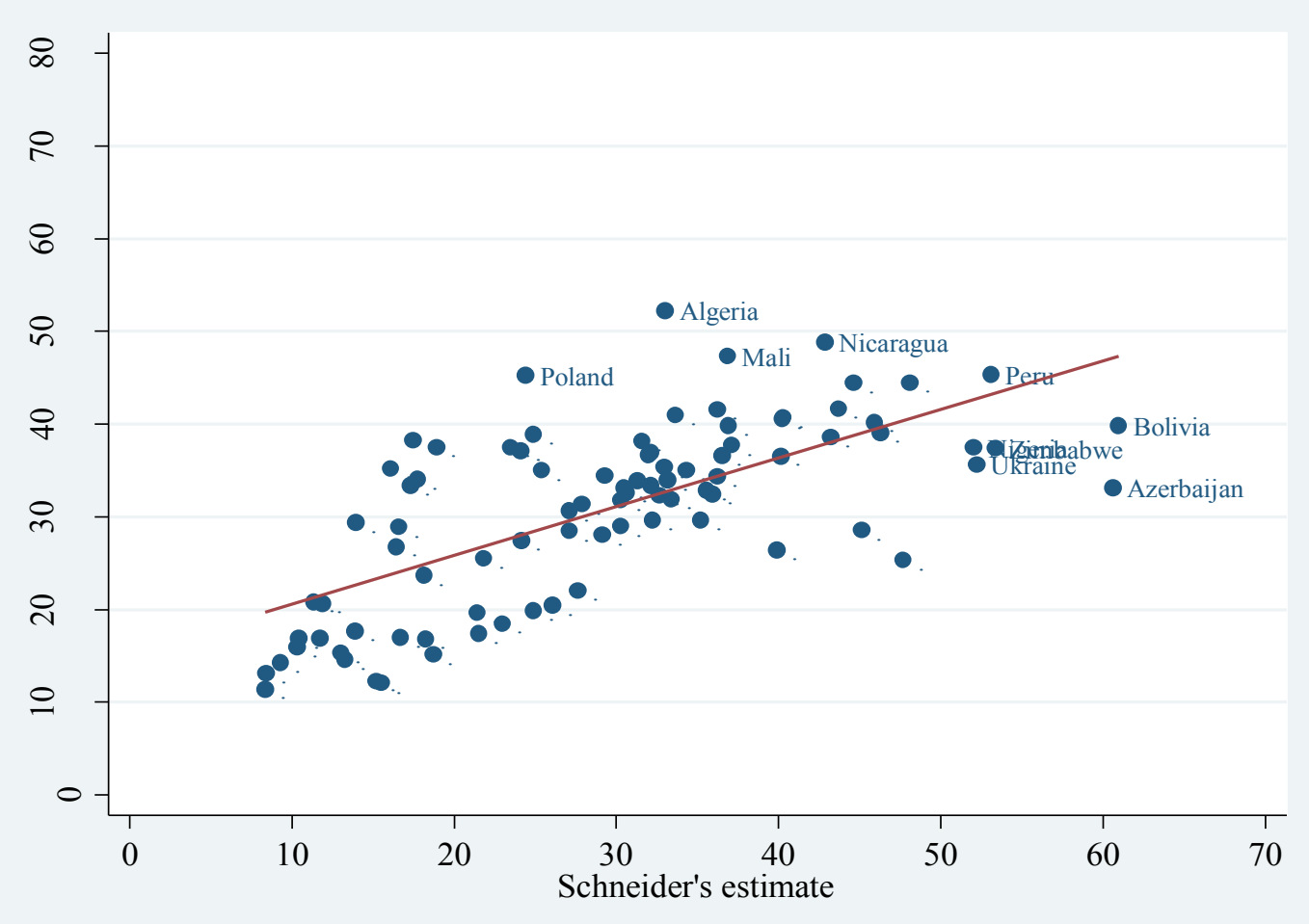


Acknowledgments

The authors would like to thank two anonymous referees for valuable comments; the authors are also grateful to Friedrich Schneider for helpful comments on earlier versions of the paper. The authors are responsible for any remaining errors.

\section{Declaration of Conflict of Interests}

The author(s) declare no potential conflicts of interest with respect to the research, authorship, and/or publication of this article.

\section{Funding}

The author(s) received no funding for the research, authorship, and/or publication of this article.

Bios

James Alm is Chair of the Department of Economics at Tulane University. His teaching and research are in the area of public economics, in such areas as tax compliance, the tax treatment of the family, income reporting, and tax reform. He has also worked extensively on fiscal and decentralization reforms overseas.

Abel Embaye is an Assistant Professor of Economics in the Department of Economics in the University of Arkansas at Fayetteville. He received his Ph.D. in economics from Georgia State University. Most of his research is on tax evasion, the shadow economy, and government spending. 


\section{Notes:}

1. The use of the currency approach to estimate the underground economy in developing countries has largely been neglected until recently. To our knowledge, only Bagachwa and Naho (1995) for Tanzania and Faal (2003) for Guyana estimate the underground economy for non-OECD countries using the currency demand method. Note that Schneider (2005) provides a range of estimates of shadow economy in developing (and developed) countries, relying mainly on his "Multiple Indicators Multiple Causes" (or MIMIC) approach. Even so, his study covers only 1991, 1995 and 2000, and his use of the MIMIC method means that the magnitude of the shadow economy is not independently.

2. Note that Schneider (2005) makes use of dynamic panel estimation methods in his estimation of the shadow economy, using his MIMIC approach. To our knowledge, we are the first to use dynamic panel estimation methods in the currency demand approach.

3. Ahumada, Alvaredo, and Canavese $(2007,2008)$ also show that, when the income elasticity of cash demand is different from unity, the velocity of money in the shadow economy can be calculated using the elasticity and velocity of money in the official economy. However, their remedy is applicable only for a particular specification of the currency equation. For example, as we discuss in more detail later, when the dependent variable is the currency to M2 ratio, the expected coefficient on the income variable is negative, and it does not have the usual interpretations of elasticity. In this case, their remedy cannot be applied.

4. One problem with having many shadow economy factors in the currency equation is that it generates a predicted shadow economy that exceeds 100 percent of GDP, theoretically possible but nonetheless suspicious result. 5. Another monetary approach was developed by Feige $(1979,1996)$, although this aproach is infrequently used. 6. However, Frey (1992) and Feld and Frey (2000) suggest that greater enforcement may actually crowd out an individual's "intrinsic motivation" to pay taxes.

7. Some time series studies use the historical minimum tax rate of countries instead of the zero tax rate to find the level of currency demand associated with the no-tax evasion situation. However, this is not the appropriate approach for this study because our sample includes a diverse cross-section of countries that have widely varying minimum tax rates. A country that has, say, a high tax rate for the current year will have a very low calculated underground economy if its historical minimum tax is also high (or close to the current year tax rate). Similarly, a country with a moderate tax rate in a given year will have its calculated underground economy appear very high if 
its minimum tax rate is very low. More fundamentally, the theoretical tax evasion literature concludes that tax evasion is a function of the current economic return from tax evasion, not the historical return.

8. Here we assume that the velocities of money in the underground and the official economy are the same, given by the ratio of GDP to the stock of legal currency. As noted above, Ahumada, Alvaredo, and Canavese $(2007,2008)$ have developed an approach that allows for different velocities in the official and the underground economies. However, their method of accounting for different velocities of money in the two sectors requires as a dependent varible the absolute quantity of money. As a result, their method cannot be applied in our case because our dependent variable is the currency to M2 ratio. We argue that this ratio is a more appropriate measure here because the ratio is unitless, and is therefore more easily comparable across countries than the absolute quantity of currency. 9. For Euro zone countries, the observations after 1999 are limited by the absence of currency data for some individual member countries. This lowers the number of observations in the estimation of currency demand equation (to 1955) but not in the estimation of the shadow economy (or 2181), because in the estimation of the shadow economy only the predicted value of currency ratio is needed, not the actual value of currency ratio.

10. We also used direct and indirect tax rates to see the separate effect of these rates on tax evasion. The results using these rates perform poorly, most likely due to the problem of multicollinearity between direct and indirect tax rates. The number of observations is also reduced when both of these tax rates are used, which likely makes the multicollinearity even more severe. These results are not reported here, but they are available upon request.

11. Note that in the raw data the lowest value for inflation was -1 (or -100 percent). Since we use a logarithmic transformation for the inflation rate in our regressions, we add 1 to this variable to make the lowest observation zero, as reflected in Table 2. All other variables are in their raw form in Table 2.

12. We have also experimented with four similarly defined dummy variables, to reflect the five income level groups in our data. We have also interacted the OECD dummy variable with the enforcement variable. These specifications generally performed poorly, and they are not reported.

13. One explanation for this result could be that the differenced lagged values of the endogenous variables (which serve as instruments for the level equation) could be correlated with the unobserved country heterogeneity.

14. We also run some robustness checks of this specification's results by regression for sub-periods of the years 1984-2006 and we have found the results to be robust across sub-periods.

15. One issue in the calculation is that there is a lagged dependent variable as a regressor in equation (2), which means that we cannot predict the currency ratio for the first year (or 1984). To avoid this, we use the steady state 
version of the equation that can be obtained by making use of the fact that $Z_{t}=Z_{t-1}$ in our equation, so that:

$$
z_{t}=\alpha z_{t-1}+\beta X_{t} \Rightarrow z_{t}=\frac{\beta}{1-\alpha} X_{t}
$$

